\title{
Antecedents of Employees' Entrepreneurial Orientation: The Role of Organizational Culture and the Enabling Environment
}

\author{
Kulsoom Arif Hahsmi* \\ Research Scholar \\ Karachi University Business School, University of Karachi, Pakistan \\ Dr. Danish Ahmed Siddiqui \\ Associate Professor \\ Karachi University Business School, University of Karachi, Pakistan
}

\begin{abstract}
There is an abundant literature on Entrepreneurship within organization, but the evidence on how it is caused, is still dispersed. Moreover, it still lacks a proper theoretical framework. Brettelet. al. (2015) used Competing Values Model in explaining the effect of organisational culture on Entrepreneurial Orientation. We modified this model, including enabling environment factors, as well as more enriched dimensions of Entrepreneurial Orientation. Hence we hypothesized that organizational culture (Clan, Hierarchical, Developmental, Rational, and Open Culture), and enabling environment (Flexibility/ support, Open Communication, External Orientation, and Team Work) affect Employees' Entrepreneurial Orientation measured by new product innovation, new organizational practice, proactivity, and risk-taking. We applied this model by conducted a survey using likert scale type questionnaire. The data was collected from 325 employees working in different organisations in Karachi. Data was analyzed using confirmatory factor analysis and structured equation modeling. The results showed that new product innovation was positively influenced by Rational Culture, Open Culture, Flexibility, and External Orientation. And negatively affected by Clan Culture. Similarly, risk taking ability is positively influenced by Developmental Culture, External Orientation, and Team Work. Proactivity is positively affected by Rational Culture, and External Orientation. Unlike Innovation, which was negatively affected by Clan culture, New Organizational Practice got positively affected along with Open Communication.

Keywords: Clan Culture, Hierarchical Culture, Developmental Culture, Rational Culture, Open Culture, Flexibility, Open Communication, External Orientation, Team Work, new product innovation, new organizational practice, proactivity, risk-taking
\end{abstract}

DOI: $10.7176 /$ RHSS/10-11-02

Publication date:June 30th 2020

\section{INTRODUCTION}

\subsection{Background to the Study}

In today's business world, innovation is a major pillar of success for all organizations. Rapidly changing technologies, shortening the product life cycle, and accelerating product development can accelerate the pace of innovation and change the nature of economic development. Innovation is currently at the heart of organizational strategies to achieve and maintain competitiveness in the market. This becomes more complex as customer needs and technology change rapidly. Innovation refers to the introduction of an organization in a new product or new product quality, production method, market, source, and / or industry. The goal is also to improve existing concepts and ideas by creating a commercially viable product using a stepwise process. Innovation tends to be very dynamic, it is considered an essential for all businesses including Multinational companies, Large Businesses, Small businesses orstart-ups. The most satisfying innovation is the ability to turn an idea into a successful concept. To do this, you must follow a long and complex process. To succeed, you need to understand the process and get the support you need. This distinguishes between successful and unsuccessful innovation processes.

Product innovation is defined as; Use of new materials or components in the development of new products, changes to established product designs, or the manufacture of established products. Many examples of product innovation include new product introductions, quality improvements, and overall performance improvements. Product innovation, cost reduction innovation, and process innovation are three types of innovation aimed at developing the company's production methods. An environment that provides the flexibility to react to change and provides psychological security, processes, and tools to leverage the creative thinking required for innovation: a new value for creating, developing, implementing, and leveraging knowledge Generate Or an improved product, service, or process. This environment is the product of two things: the organization's members-management style, its value, behavior, attitude, communication style, and shared business practices-and infrastructure (policies, processes, etc.). And system).

Innovation is a key indicator of an organization's ability to sustain success. And in today's uncertain and complex global business environment, the ability to remain successful through a culture of innovation is becoming 
increasingly important. The "innovation culture" provides a competitive advantage (Shahzad, 2017).

The culture of the organization is visible to employees and customers. Stories told about the organization by employees and customers give insight into the culture of the organization. If you are affecting an individual, you are affecting the team, which is affecting the organization. Before you can affect the whole thing, you need to affect the part. The reverse is also true. The vision, strategy, and direction defined at the organizational level influence teams and individuals. Culture is born from the top. The CEO and management team are primarily responsible for the culture of the organization. Their leadership style, values, behaviors, and working methods set the tone of the organization's culture. Therefore, if an organization wants a culture of innovation, management must take the lead in defining its intent, communicating it throughout the company, and demonstrating its commitment through innovation. Through his own actions and involvement in the process of achieving innovation.

Organizational practices that provide enabling environment are located just outside the core culture. They are not elements of basic culture. It is rather action that translates ideals into actions. In short, they make use of culture. Organizational Practices are the behaviors \& actions in an organization. The Organizational Practices convert the values and ideals in an organization's culture into practical actions and movements that keep the organization running actively, and more importantly on an upward trajectory in terms of business and profit margins. It is important that an organization follows good practices that are good enough to sort things in place and to ensure the processes move in the right direction and to ensure timely identification of problems for improvements.

Mergers and acquisitions are responsible for cultural issues. Even a well-functioning organizational culture can develop into a malfunctioning culture after the merger. Research shows that two of the three mergers fail due to cultural issues. By mixing and redefining cultures and reconciling those differences, we are building a common platform for the future. In recent years, the rapid pace of mergers and acquisitions has changed the way companies merge. Mergers have focused on cultural fusion and achieving specific business goals. Some experts believe that a strong corporate culture will naturally develop if the right business plans and programs are implemented at the time of the merger.

In this era of globalization and homogenization, does culture still play a role in predicting corporate risktaking behavior? And if so, how exactly does culture impact corporate decisions? Are there certain aspects of a culture that are more influential than others in terms of shaping corporate risk taking? Does culture directly influence corporate strategies or does it have more of an indirect affect? Moreover, does the impact of culture vary across corporations and do firm characteristics matter? Scholars in a variety disciplines have been debating these questions for years. Some scholars discount the importance of culture in understanding corporate behavior. For instance, some economists argue that corporate decisions should be explained by profit maximization arguments rather than by intangible factors like culture. However, others believe context does matter and that culture affects corporate behavior, including risk taking. If this is the case, then it is natural to ask whether cultural impact is direct or indirect. In other words, does the cultural impact on the formation of national institutions matter more than the impact culture has on managerial attitudes in terms of predicting corporate risk-taking behavior? Previous empirical research has been inconclusive about the question of whether cultural characteristics directly or indirectly shape corporate risk taking.

\subsection{Problem Statement}

Entrepreneurial orientation is an important theory. Executives craft strategies with the hope or idea of achieving something innovative and utilizing chances that other firms cannot utilize. Entrepreneurial orientation is basically the practices, processes, styles of decision making that operate entrepreneurially. Entrepreneurial orientation of an organization can be understand with the help of competitive aggressiveness, pro-activeness, new organizational practices, autonomy, innovativeness and risk taking. Entrepreneurial orientation was developed in order to adapt rapid changes in the modern global environment for the business survival. Entrepreneurial orientation also affects the growth of the firm.

Entrepreneurial orientation face a lot of challenges like lack of training and educational facilities, insufficiency of capital (in contrast to western nations, due to increase in prices it has become difficult to sustain people's standard of living), socio cultural elements also contribute towards slow growth of entrepreneurship, opposition of changes and innovation, insufficient facilities of incentives and government, heavy corruption and taxation, lack of human and physical resources, deficiency of technical structure like professional managers, trained and specialist employees are required, risk regarding loss of invested money and lack of interest towards work etc.

\subsection{Gap Analysis}

Shahzad et al, (2017) investigated the impact of organizational culture on innovation performance. The outcomes indicated that organizational climate, external orientation, teamwork, employees' empowerment and support to change/ flexibility significantly affects innovation performance. Laforet, (2016) also examined the connection between organizational culture and organizational innovation. The results indicate that flexible, open culture, 
external oriented and long term orientation positively effects organizational innovation and open communication negatively influence organizational innovation. However, detailed explanation of cultural factor were not discussed, neither proactiveness nor risk taken were focused which could be crucial for innovation.

Cherchem, (2017) investigate the connection between organizational culture and entrepreneurial orientation. The outcomes showed that clan culture highly encourage entrepreneurship orientation (when single generation was involved). Hierarchical culture also highly encourages entrepreneurship orientation (when multiple generations were involved). Similarly, Engelen et al, (2014) studied the linkage between organizational culture and entrepreneurship orientation. The outcomes revealed that adhocracy culture (positively affects) foster organization's entrepreneurship orientation level. Whereas clan culture, market cultures and hierarchical culture negatively affects entrepreneurship orientation. However, they both lacked innovation component.

Brettel et al, (2014) examined the influence of organizational culture on innovativeness, proactiveness, and risk-taking. The results of the study showed that group, developmental and rational culture positively influences innovativeness, risk-taking and proactiveness. While hierarchical culture negatively affects innovativeness, risktaking and proactiveness. However, they fall short in explaining enabling environment factors, as well as different dimensions of Entrepreneurial Orientation. There is an abundant literature on Entrepreneurship within organization, but the evidence on how it is caused, is still dispersed. Moreover, studies either focused on innovation component or entrepreneurship. These two factors were not studies before in a combined framework. Moreover, despite a fair number of papers on interactions between organizational culture and innovation, as mentioned earlier, attempts to combine the open innovation model and organization culture have been scarce (Katila, Ahuja, 2002), (Laursen, Salter, 2006), (Inauen, Schenker-Wicki, 2011) \& (Rass et al., 2013) and therefore worth undertaking. We modified Brettelet. al. (2015)'s Competing Values Model to include enabling environment factors, as well as more enriched dimensions of Entrepreneurial Orientation. No such study was conducted on Pakistan combining diverse factors like teamwork, external orientation, developmental culture, rational culture, clan culture, open culture, open communication, flexibility/ support to change, hierarchical culture (altogether) and entrepreneurial orientation was measured by innovativeness, risk-taking, new organizational practice and proactiveness, in a single structural model.

\section{Research Objectives}

This study is a quantitative research to identify the effect of independent variable i.e. organizational culture on the dependent variables i.e. new product innovation, new organizational practice, proactivity and risk-taking. The subvariables of organizational culture are; clan culture, hieratical culture, developmental culture, rational culture, open culture, flexibility/ support to change, open communication, external orientation and teamwork. The reason of this study is to identify the effect of organizational culture through different factors new product innovation, new organizational practice, proactivity and risk-taking.

The general objective of this investigation was that what elements affect entrepreneurial orientation and what measures should be taken to overcome these problems. The specific problem of this research was to find out the influence of organizational culture on entrepreneurial orientation.

The objective of this study includes the effect of organizational culture on new product innovation, new organizational practice, proactivity and risk-taking. It is based on the exceeding research problems, the research objectives are as follows:

1. To determine the effect of organizational culture on new product innovation.

2. To determine the effect of organizational culture on new organizational practice.

3. To determine the effect of organizational culture on proactivity.

4. To determine the effect of organizational culture on risk-taking.

\subsection{Research Question}

- What is the impact of clan culture on new product innovation?

- What is the impact of clan culture on new organizational practice?

- What is the impact of clan culture on proactivity?

- What is the impact of clan culture on risk-taking?

- What is the impact of hierarchical culture on new product innovation?

- What is the impact of hierarchical culture on new organizational practice?

- What is the impact of hierarchical culture on proactivity?

- What is the impact of hierarchical culture on risk-taking?

- What is the impact of developmental culture on new product innovation?

- What is the impact of developmental culture on new organizational practice? 
- What is the impact of developmental culture on proactivity?

- What is the impact of developmental culture on risk-taking?

- What is the impact of rational culture on new product innovation?

- What is the impact of rational culture on new organizational practice?

- What is the impact of rational culture on proactivity?

- What is the impact of rational culture on risk-taking?

- What is the impact of open culture on new product innovation?

- What is the impact of open culture on new organizational practice?

- What is the impact of open culture on proactivity?

- What is the impact of open culture on risk-taking?

- What is the impact of flexibility/ support or change on new product innovation?

- What is the impact of flexibility/ support or change on new organizational practice?

- What is the impact of flexibility/ support or change on proactivity?

- What is the impact of flexibility/ support or change on risk-taking?

- What is the impact of open communication on new product innovation?

- What is the impact of open communication on new organizational practice?

- What is the impact of open communication on proactivity?

- What is the impact of open communication on risk-taking?

- What is the impact of external orientation on new product innovation?

- What is the impact of external orientation on new organizational practice?

- What is the impact of external orientation on proactivity?

- What is the impact of external orientation on risk-taking?

- What is the impact of teamwork on new product innovation?

- What is the impact of teamwork on new organizational practice?

- What is the impact of teamwork on proactivity?

- What is the impact of teamwork on risk-taking?

\subsection{Significance}

Historically, there are a lot of researches were conducted on organizational culture and entrepreneurial orientation but no one has ever conduct a comparative or nexus research in which organizational culture was measured by teamwork, external orientation, developmental culture, rational culture, clan culture, open culture, open communication, flexibility/ support to change, hierarchical culture (altogether) and entrepreneurial orientation was measured by innovativeness, risk-taking, new organizational practice and proactiveness (altogether).

This study can benefit organizations in analyzing how different type of organizational culture effect the new product innovation, organizational practice, proactiveness and risk-taking. The organizational culture play a key role in performing work done within the organization. In addition, this study would also be beneficial for executive management of the organization in evaluating the best organizational practice.

\section{Literature Review}

In the context of culture-innovation relationships, useful insights are to be found in a survey of 852 small and medium-sized Polish firms by Mazur, Rószkiewicz and Strzyżewska $(2008,2011)$. The findings showed that the top ranked companies in all three knowledge practice categories (which can be interpreted as companies characterized by a strong knowledge culture) performed the best. What is also interesting, those companies were managed by knowledge oriented leaders (leaders of high level knowledge orientation). (Donate, Guadamillas, 2011) also contended that innovative culture will support their innovation practices.

Li et al, (2013) examined both the direct and indirect ways in which culture can influence corporate risk taking. The paper suggests that culture will have more of an impact when managers have more discretion. And discretion tends to be greater in smaller firms. Consequently, managers in smaller firms should be more likely to engage in riskier behavior compared to their counterparts in larger firms (which typically have more management control systems in place that act to constrain managerial behavior).

Naïma Cherchem (2017) examine that in family firms, organizational culture evolves through an ongoing dynamic process of intergenerational interaction. The study draws from the Competing Values Framework to examine the extent to which generational involvement shapes the effects of clan culture and hierarchical culture 
on Entrepreneurial orientation. From a quantitative study of 106 family SMEs, the results show that there is no single cultural path for developing and maintaining long-term family firm's entrepreneurial orientation. While clan culture fosters higher levels of entrepreneurial orientation when only one generation is involved Li et al, (2013) examined both the direct and indirect ways in which culture can influence corporate risk taking. The paper suggests that culture will have more of an impact when managers have more discretion. And discretion tends to be greater in smaller firms. Consequently, managers in smaller firms should be more likely to engage in riskier behavior compared to their counterparts in larger firms (which typically have more management control systems in place that act to constrain managerial behavior).

(Nordqvist, M. 2010) offers insights through the lens of dynamic capabilities, which are created by knowledge and in turn generate entrepreneurial performance and value creation. The result find that family inertia depends on characteristics of the family business culture, where paternalism and entrepreneurial orientation influence family inertia positively and negatively, respectively. Family firms from Switzerland and Italy active in the beverage industry represent the empirical context.

Gursoy (2016) study the aims at revealing relationship between innovative culture and intrapreneurship. It aims to find answers to: how innovative culture affects entrepreneurship, what the relationship between innovative culture and intrapreneurship is, and what extent innovative culture supports creating new strategies and plans. The study finds out that innovative culture has a significant and positive effect on intrapreneurship, on aggregate and by its dimensions.

Livari (2007) analyzed the relationship between organizational culture and the deployment of systems development methodologies. The results show that the deployment of methodologies by IS developers is primarily associated with a hierarchical culture that is oriented toward security, order, and routinization. IT managers' critical attitudes of the deployment of methodologies in organizations with a strong rational culture (focusing on productivity, efficiency, and goal achievement) is also worth noting.

Sylvie Laforet (2016) examine the effects of organisational culture on organisational innovation performance in family small and medium-sized enterprises. A postal survey of family SMEs across sectors in the UK is conducted. The findings show that a paternalistic and founder culture type do not have a positive effect on family firm innovation performance, but an entrepreneurial-like culture does, i.e. one that is externally oriented, flexible, proactive and long-term oriented. Similarly, an inward focus culture such as, the founder culture impedes innovation; while an outward focus culture such as, an external orientation culture has a positive effect on family firm innovation performance. This study makes valuable contributions to the understanding of theory and practices of innovation in family businesses.

Nazamul Hoque (2013) develop model of organisational culture from Islamic point of view. In the study. The salient features are trust on Allah, missionary zeal, justice, accountability, mutual respects, mutual trust, absolute sincerity, hardworking, cooperation, excellence, brotherly treatment, honesty and truthfulness, morality, consultative decision making, knowledge, good behaviour, sacrifice, neat and cleanliness. The findings of the research can be used as a guide to Islamic organisational culture in Muslim countries.

\section{Theoretical Framework \\ New product innovation}

Product innovation is a vital task for the modern corporation. The company's success at new product conception, development and launch decides the fate of the entire business.

Product innovation can come in three different forms. 1) The development of a new product. 2) An improvement of the performance of the existing product. 3) A new feature to an existing product. This innovation can be in the product's own functionality, or it can take the form of new technology.

An innovation must differentiate itself from the competition and be distinguished by at least one unique feature. This differentiating feature should be highly relevant for the user and should be able to be maintained in the long term. Product innovation includes the initiatives, methods, techniques, and processes for making incremental improvements to existing products and services. It involves making evolutionary changes to the products employing the prevailing technologies and organizational capabilities or a new way to do something.

This includes significant improvements in technical specifications, components and materials, incorporated software, user friendliness and other functional characteristics. They must also solve an existing problem in a new and exciting way. Or the product needs to solve a completely new problem that has arisen.

As product innovation relates to both the development of new products and the improvement of existing products so this improvement can refer to changes in design or use of new materials or components in manufacturing of established products. The profitability of these products is affected greatly by the extent to which they are meaningfully differentiated from competing alternatives. Product development and innovation allows companies to gain competitive advantage, attract new customers, retain existing customers, and strengthen the relationships with their distribution channels (Keller, 2003). The organizational heritage of the firm will influence its future decisions regarding the markets in which it will operate. 
For several organizations, successful product innovation is an engine of growth (Pauwels, Silva-Risso, Srinivasan, and Hanssens, 2004). This is because products with unique and differentiated features provide additional value to customers, and thus, influence their purchasing decision. In large organizations which successfully managed to build trustworthy brand names worldwide, innovation is becoming their common practice to create positive perception among customers. One of the possible means to ensure innovations comes from a firm's ability to come up with quality products and attractive product designs such as the case of automotive.

\section{New organizational practice}

In the twenty-first century, organizations face many new challenges. The society and the economy have changed so radically that the last century's management practices and theories are no longer relevant. Almost everything we do today as individuals or organizations requires us to interact with large-scale institutions. The new organizational forms literature argues that in a dynamic business environment, 'new' ways of organizing are required to ensure speed, flexibility and innovation.

In today's world, the structure, content, and process of work have changed. Work is now more cognitively complex, more team-based and collaborative, more dependent on social skills, more dependent on technological competence plus time pressured and more mobile and less dependent on geography. New work practices have been adopted such as job rotation, delayering, self-directed work-teams, just-in-time and total quality management. The consequences of these organizational changes on firms performance and skill requirements are widely seen.

Using either industry or firm-level data, most of these work display a positive impact of new work practices upon productivity especially in connection with information technologies. Forces that are significantly shaping management practices today include the pace of change, technology, globalization, diversity, and social expectations. Although many other factors ultimately contribute to the changing patterns of work, organizational theorists point to two key drivers:

- Increasing pressures on organizations to be more competitive, agile, and customer focused-to be a "lean enterprise."

- Communication and information technology breakthroughs, especially mobile technologies and the Internet that enable work to be separated from time and space.

Due to these new work practices organizations today are agile and focused on identifying value from the customer perspective. They are now more tuned to dynamic competitive requirements and strategy, less hierarchical in structure and decision authority plus less likely to provide lifelong careers and job security along-with continually reorganizing to maintain or gain competitive advantage.

\section{Proactive behavior}

Active action means not just reacting, but acting before future situations. It means not only adapting to the situation but also waiting for something to happen, taking control and moving things. Active employees usually do not need to be asked to act and do not require detailed instructions. Proactive behavior contrasts with other job-related behaviors such as proficiency that is, meeting predictable job requirements, addressing, adapting to change, and providing support. By other members of the organization. With regard to the latter aspect, adaptability consists of reacting to change, but aggressiveness is about causing change. Proactive is not limited to additional roll performance behavior. Employees can play a proactive role. Similarly, actions labeled as organized citizen actions can be actively or passively adopted. Proactive behavior at work has received considerable scholarly research attention over the past fifteen years. It has not, however, emerged as an integrated research stream in the organizational behavior literature. There is no single definition, theory, or measure driving this body of work; rather, researchers have adopted a number of different approaches toward identifying the antecedents and consequences of proactive behavior, and they have examined them in a number of seemingly disconnected literatures. Proactive behavior has been conceptualized and measured in a variety of ways, a definition of proactive behavior that captures the essence of the various approaches must be coarse grained.

\section{Risk-taking}

Miller and Friesen (1983) describe risk as degree accepted by top management for failure bringing high cost. Covin and Slevin (1991) define risk taking as "execution of investment decisions and strategic aims under uncertain conditions". In terms of entrepreneurship, risk are given decisions, with regards to uncertainty and business under risk, towards new product, market, process, and enterprises (Cornwall and Perlman, 1990). To intrapreneurs, risk undertaken by employees depends on top administration risk appetite. Under uncertainty, management's degree of accepting failure has an effect on intrapreneur's later decisions.

The tolerance of uncertainty in the organization. In the high risk-taking case, decisions and actions are prompt and rapid, arising opportunities are taken and concrete experimentation is preferred to detailed investigation and analysis. In a risk-avoiding climate there is a cautious, hesitant mentality. People try to be on the "safe side". They decide "to sleep on the matter". They set up committees and they cover themselves in many ways before making 
a decision. (Ekvall, G. 1996)

Risk is defined as the probability of an event and its consequences. Risk management is the practice of using processes, methods and tools for managing these risks. Running a business comes with many different types of risk. Some of these potential hazards can destroy a business while others can cause serious damage that can be costly and time-consuming to repair. Business Risk management is a subset of risk management used to evaluate the business risks involved if any changes occur in the business operations, systems and process. It focuses on identifying what could go wrong, evaluating which risks should be dealt with and implementing strategies to deal with those risks. Businesses that have identified the risks will be better prepared and have a more cost-effective way of dealing with them. It identifies, prioritizes and addresses the risk to minimize penalties from unexpected incidents, by keeping them on track. It also enables an integrated response to multiple risks, and facilitates a more informed risk-based decision making capability.

If and when a risk becomes a reality, a well-prepared business can minimize the impact on earnings, the lost time and productivity, and the negative impact on customers. The ability to identify which risks pose a threat to successful operations is a key component of strategic business planning. Business risks are identified using various methods, but each identifying strategy relies on a comprehensive analysis of specific business activities that could present challenges to the company. It should be understood that continuing on the same path for too long is a recipe for stunted growth and falling behind in your industry. The key is in the syntax; taking a risk is never going to be danger-free but taking a calculated risk brings a higher chance for rewards. By calculating the outcomes you are lessening the potential harm and increasing your odds of a positive outcome.

Managers are faced with making decisions throughout their work day. Some decisions are routine or easy, while others are complicated and risky. Certain types of people enjoy taking risks, while others prefer stability and are averse to any type of risk. A risk taker is someone who risks everything in the hope of achievement or accepts greater potential for loss in decisions and tolerates uncertainty. However, it also has its own limitations, factors considering human involvement in decision making. Human judgment can sometimes be based on past experience or sheer gut feeling, which may or may not work at all times. Simple errors or mistakes can turn the business upside down. This could also happen when two or more people are involved and they fail to come to same understanding or accept a decision in confused state of mind/ haste. These limitations preclude a management from having absolute assurance towards the achievement of the entity's objectives.

\section{Organization's culture}

An organization's culture defines the appropriate way to act within the organization. This culture is made up of common beliefs and values that have been established by leaders and communicated in a variety of ways that ultimately shape employee awareness, behavior and understanding. Because the sector and situation are quite different, there is no single cultural model that meets the needs of all organizations

According to (Conrad, 2012) "organizations are embedded in societies and cannot be understood outside of a society's beliefs, values, structures, practices, tension and ways of managing those tensions".. (Schein, 2004) defines organizational culture as "a pattern of shared basic assumptions that was learned by a group as it solved its problems of external adaptation and internal integration that has worked well enough to be considered valid and, therefore, to be taught to new members as the correct way to perceive, think, and feel in relation to those problems"

Organizational cultures may be more or less ethical (Riivari et al., 2012), and more or less innovative. Organizational culture can be more or less conducive to innovating, but innovation culture does not exist separate from the general culture of a business entity. As such, innovative culture is achieved through the process of organizational culture modifications (Simpson et al., 2006) supporting new knowledge creation by adopting new ideas (products) and behavior (Herkema, 2003).

\section{Clan Culture:}

Clan culture is a type of corporate environment such as a family or group or a tribe that emphasizes the compromise and unity of aims and values. In clan culture on an organization employee's engagement and commitment are considered to promote the ability and loyalty that drive productivity and business success. According to Hill, (2013) Clan culture is based on collaboration, and organizations are more focused on employee value and satisfaction, which leads to increased organizational productivity.

A clan culture is characterized by altruism, which is considered to foster loyalty and commitment to the collaborative strategy and family's long- term prosperity. Hence, clan culture is associated with a group-based approach to entrepreneurship because it accentuates collaboration in the entrepreneurial decision-making, and favours rewarding individuals when they share their knowledge. Based on the works of Cameron and Quinn (2006), clan culture is characterized by tradition and loyalty. It emphasizes cohesion and collaboration, and encourages members to embrace the firm's values and goals.

Clan culture is associated with a high level of trust among the different actors in an organization. Higher 
levels of trust will further lead to stronger interpersonal cohesion and loyalty, thus boosting internal collaboration and knowledge exchange across different functional boundaries, which is expected to drive a firm's innovativeness. Furthermore, an organization's emphasis on flexibility facilitates "organic structures," which represent the opposite of mechanistic and stable structures (Gursoy 2016)

$\mathrm{H}_{1 \mathrm{a}}$ : There is a significant relation between clan culture and new product innovation.

$H_{1 b:}$ There is a significant relation between clan culture and new organizational practice.

$\mathrm{H}_{1 \mathrm{c}}$ : There is a significant relation between clan culture and proactivity

$H_{1 d:}$ There is a significant relation between clan culture and risk-taking.

\section{Hierarchical Culture:}

A hierarchical culture is an organizational typical model based on visibly well-defined corporate stages and structures. In a business environment, hierarchies hinge on structure, rules and top-down control to monitor business practices and actions. Hierarchical culture refers to the management of a consecrated culture according to a standardized structure, which makes its functioning effective and efficient. This type of culture emphases on rules, guidelines, regulations and policies and is more formalized compared to other forms of culture (Hill, 2013). A hierarchical culture displays an emphasis on internal focus but differs through its focus on stability. It can further be characterized by a focus on security and routinization, and it is oriented toward control, stability, and efficiency (Iivari and Huisman 2007). In hierarchical cultures with centralized structures, the decision authority is usually limited to one manager or to only a few managers (Bunderson 2003), which strongly affects the processing of information in an organization.

$\mathrm{H}_{2 \mathrm{a}}$ : There is a significant relation between hierarchical culture and new product innovation.

$H_{2 b}$ : There is a significant relation between hierarchical culture and new organizational practice.

$\mathbf{H}_{2 \mathrm{c}}$ : There is a significant relation between hierarchical culture and proactivity

$\mathbf{H}_{2 \mathrm{~d}}$ : There is a significant relation between hierarchical culture and risk-taking.

\section{Developmental Culture:}

Developmental culture means the capability to adapt rapidly to changing circumstances. According to Hills (2013), developmental culture is focusing more on bringing creativity and innovation in the organization. These values are expected to induce rigidity within the family firm's structure, and reduce organizational flexibility and decentralization, which are fundamental characteristics when family firm is small sized, in other word, when there is only one generation involved. This flexibility enables family firms to exploit entrepreneurial opportunities (Zahra et al., 2008). In contrast, centralization and formalization values have been found to lead to lower levels of innovation, proactivity and risk taking activities. Hence, the hierarchical culture aspects stifle family firms in their efforts to pursue entrepreneurial activities (Zahra et al., 2004) when only one generation is involved.

$\mathrm{H}_{3 \mathrm{a}}$ : There is a significant relation between developmental culture and new product innovation.

$H_{3 b}$ : There is a significant relation between developmental culture and new organizational practice.

$\mathrm{H}_{3 \mathrm{c}}$ : There is a significant relation between developmental culture and proactivity

$H_{3 d}$ : There is a significant relation between developmental culture and risk-taking.

\section{Rational Culture:}

Rational culture is characterized by an importance on constancy and an external focus with output, efficiency, and objective achievement as its fundamental values (Iivari and Huisman 2007) Employees are encouraged to set difficult goals and strive to achieve them. Employee performance is closely monitored and often directly rewarded or punished. The emphasis on individual performance is thought to lead to greater achievement for the individual employee and, as a result, greater success for the organization.

Rational culture is strongly goal-oriented, this has a major impact on how the organizational members interact. Collaboration and close integration of different departments within organizations are considered as a central element in fostering EO (Morris et al. 2007). Depending on the underlying organizational culture, intense integration may lead to intensive social ties with a negative effect on an organization's innovativeness (Sethi, Smith, and Park 2001).

$\mathrm{H}_{4 \mathrm{a}}$ : There is a significant relation between rational culture and new product innovation.

$H_{4 b}$ : There is a significant relation between rational culture and new organizational practice.

$\mathbf{H}_{4 \mathrm{c}}$ : There is a significant relation between rational culture and proactivity

$\mathrm{H}_{4 \mathrm{~d}}$ : There is a significant relation between rational culture and risk-taking.

\section{Open Culture:}

An open culture is one that even large organizations strive to achieve in order to grow. Google touts an open culture and attributes the company's success to its culture. An open culture can bring in vibrant thinking, a long term vision, advancement, and an empathy for each other, all of which can drive the organization headlong. An 
open culture, which is based on entrepreneurial orientation, acts family inaction so as to positively affect resourcerecombination processes. An entrepreneurial orientation (in terms of innovativeness, pro-activeness and risk taking) may allow a firm to overcome the inflexibility trap of organisational capabilities by updating them repeatedly. As the environment changes, organisational adaptation becomes more necessary, and past patterns and behaviors less appropriate.

An open culture fosters entrepreneurial action, and thereby positively affect the recombination of internal and external resources. With stable levels of knowledge and a closed culture, the firm is not able to foster change and generates value over time.

$H_{5 a}$ : There is a significant relation between open culture and new product innovation.

$H_{5 b}$ : There is a significant relation between open culture and new organizational practice.

$H_{5 c}$ There is a significant relation between open culture and proactivity

$H_{5 d}$ : There is a significant relation between open culture and risk-taking.

\section{Flexibility/ support or change:}

Flexibility is the capacity to adjust to short-term change quickly and calmly, so that employee can deal with unexpected problems or tasks effectively. Flexibility can be defined as the organization adapting to size, composition, responsiveness and the people, their inputs and costs required to achieve organizational objectives and goals. Organizational flexibility can also be defined when work gets done, where it gets done and how work gets done.

Flexibility reflects an organization's ability to adapt to changing conditions and requirements, and is affected by issues such as training, management, and outsourcing. The capability of an organization to employ customerfocused people at every level and build processes not only simple to execute but also flexible enough to survive and compete effectively with a changing environment.

Flexibility represents the ability of a manufactural system to adapt to some diversified tasks of production, thus to assure an economic efficiency - the rapport time/cost should be optimum, with insignificant structure changes within a long period of time. The central role of flexibility is to permit the survival and the success of the organizations in a turbulent circumstance, which is characteristic to the new world tendencies. The more flexible the organization becomes, the better it responds to the change. Firms, which are flexible, facilitate creativity, innovations and speed, all these being included into the organizational and coordination processes. In quick change conditions, flexibility is a competitive advantage. An organization should face both threats and inherent opportunities in an uncertain future and in an instable circumstance. Flexibility and promptitude are the qualities of the organizational success and the need to be flexible is an imperative of competition.

$H_{6 a}$ There is a significant relation between flexibility/ support or change and new product innovation.

$H_{6 b}$ There is a significant relation between flexibility/ support or change and new organizational practice.

$H_{6 c}$ : There is a significant relation between flexibility/ support or change and proactivity

$H_{6 d:}$ There is a significant relation between flexibility/ support or change and risk-taking.

\section{Open Communication:}

Open communication means is where employees are encouraged to share their thoughts and concerns, both good and bad, without the worry of retaliation from management when the feedback is bad. Open communication is an important instrument businesses, to improve the efficiency and effectiveness among the employees. Open communication occurs when all parties are able to express ideas to one another, such as in a conversation or debate. Open communication is an important tool businesses, universities, nonprofit organizations and other organizations can use to improve their groups' efficiency and effectiveness. Organizations that want to stay current with their structures and practices and those that have a desire to always learn should implement open communication practices. Open communication helps organizations improve. Information is not filtered through several levels of management, but instead it is filtered through fewer levels. It is more direct from the upper levels to the lower levels and vice versa. Conflict is more calmly and appropriately dealt with when all levels of stakeholders know what is going on within the organization and the future direction of the organization's activities.

\section{External Orientation:}

An external cultural orientation (EO) is guided by the customers and other market or external forces. It focuses on the gathering of market or external information to create better insights into new and emerging opportunities for the firm. The external orientation involves a limited pre-study of the organization where the fieldwork project will be carried out and the sector in which the organization is active. The objective of the external orientation is to obtain the information and insights needed for a successful intake meeting.

External orientation significantly emerges a strong culture within the organization to motivate an employee for knowledge sharing and improving abilities to determine the opportunities for the organization. External orientation based on market direction and firm's adaptability with the extreme situation and adjacent connection 
with the customers and versatility via familiarity to market is also necessary for suitable innovation performance. External orientation is a key factor to increase the innovative organizational performance described the external orientation as fulfilling current and future requirements of potential customers as well as measuring the change in customer's expectations and sharing concerned information within the organization.

$\mathrm{H}_{8 \mathrm{a}}$ : There is a significant relation between external orientation and new product innovation.

$H_{8 b}$ : There is a significant relation between external orientation and new organizational practice.

$\mathrm{H}_{8 \mathrm{c}}$ : There is a significant relation between external orientation and proactivity

H8d: There is a significant relation between external orientation and risk-taking.

\section{Team-work:}

Team work is a group of people with different skills and different tasks, who work together on a common project, service, or goal, with a meshing of functions and mutual support. Teamwork is working respectfully and effectively with a group and doing your share. Many basic character strengths, such as communication, self-control, and humility, support a person's ability to work on a team. Teamwork is more than getting along with people. The key to being a good team player is the ability to put a group's needs above your own.

Teamwork involves a set of interdependent activities performed by individuals who collaborate toward a common goal. Teamwork involves a set of tasks and activities performed by individuals who collaborate with each other to achieve a common objective. That objective can be creating a product, delivering a service, writing a report, or making a decision. Teamwork differs from individual work in that it involves shared responsibility for a final outcome. Teamwork is important in an organization because it provides employees with an opportunity to bond with one another, which improves relations among them. Teamwork increases the accountability of every member of the team, especially when working under people who command a lot of respect within the business. Teamwork holds a highly valuable place in organizations, with teamwork among employees every bit as important as collaboration among members of a sporting team.

$\mathrm{H}_{9 \mathrm{a}}$ : There is a significant relation between teamwork and new product innovation.

$\mathrm{H}_{9 \mathrm{~b}}$ : There is a significant relation between teamwork and new organizational practice.

$H_{9 c:}$ There is a significant relation between teamwork and proactivity

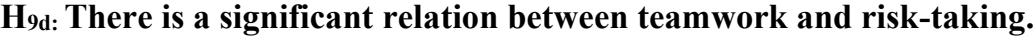

\section{Research Model:}

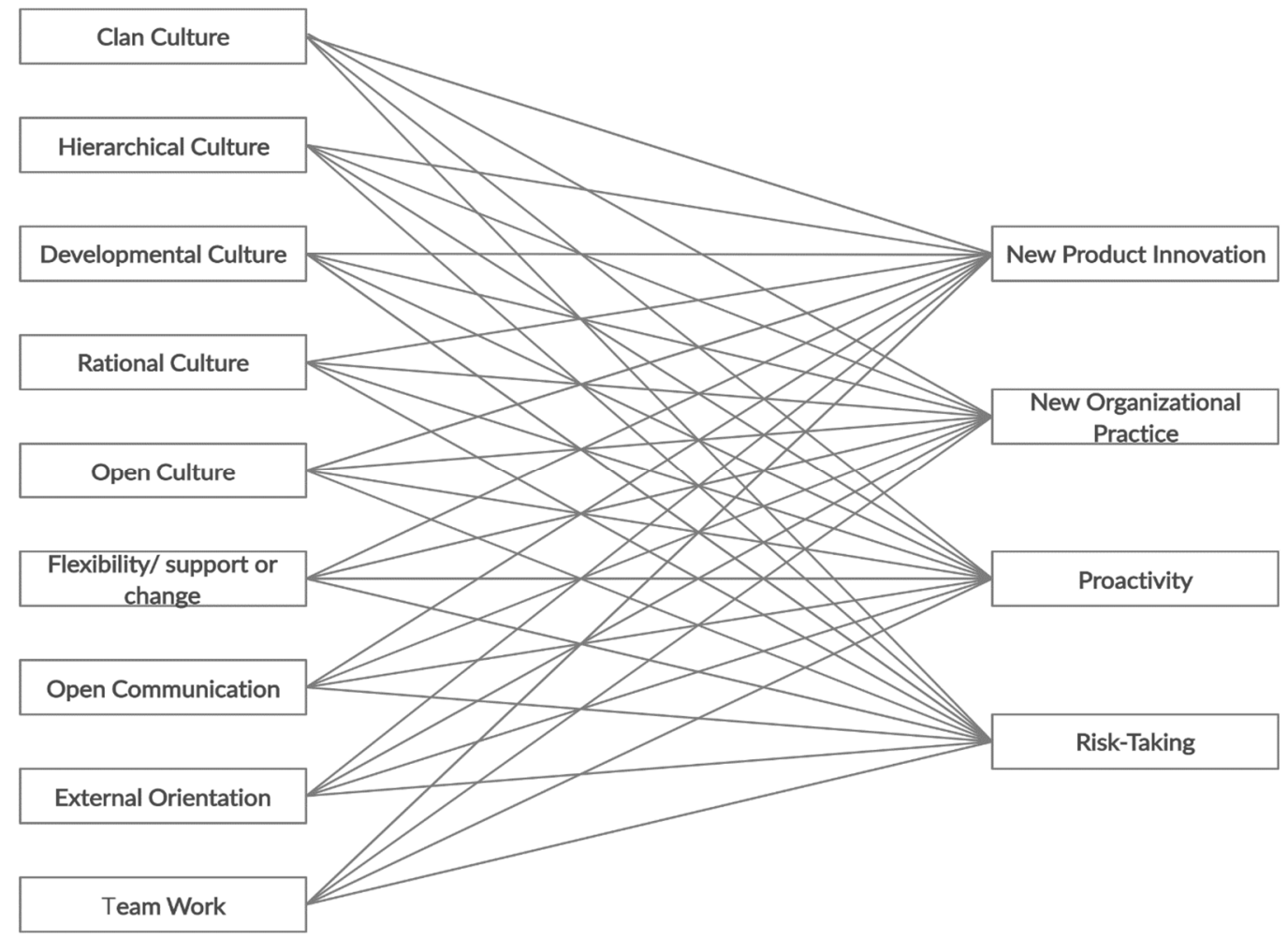




\section{METHODOLOGY}

\section{Sampling:}

Population for this research was the employees who are working in different organizations. The sample chosen for this research paper is 300 out of 320 . In this research project, primary data had been collected by using survey questionnaires method. Questionnaires were distributed to the employees who are currently working in any organization.

The data gathered from the questionnaires were entered into SmartPLS where PLS Algorithm and bootstrapping has been applied to explore the effect of organizational culture on new product innovation, new organizational practice, proactivity and risk-taking of the employees working in different organizations. To conduct the responses, individuals who are working as teacher's in different privately owned institutes of Karachi are selected for the analysis of the results.

\section{Measurement:}

The instruments for this research is adapted from different researches. The variables organizational culture, an external orientation, flexibility, open culture, open communication, new product innovation and new organiz ational practice is adapted from Laforet, S. (2016). The variable clan culture and hierarchical culture is adapted from Cherchem, N. (2017). The variable teamwork is adapted from Shahbaz, M. (2017). The variable rational culture and developmental culture is adapted from Guven, B. (2016) and the variables proactivity and risktaking is adpted from Flatten, T. C. (2015).

\section{DATA ANALYSIS}

Survey questionnaires were used to gather data that is now tested by the help Smart PLS 3 software (Ringle et al., 2005). Numerous techniques including, Descriptive analysis, EFA, CFA, PLS Algorithm and SEM are conducted in order to obtain results and to finalize this research. And for the purpose of testing path co-efficient and loading Bootstrapping is one of the best techniques (Chin, 1998 and Gil-Garcia, 2008).

\subsection{Data Screening:}

Data Screening is a process that makes sure your data is useable, reliable and valid for further processing it is done before applying different statistical techniques. Data screening includes analysis of missing values in the gathered data along with data coding and outliers among the responses collected from the respondents.

\subsection{Structural Equation Modelling:}

Structural equation modeling (SEM) is a combination of different statistical analysis technique used to analyze the structural association of the study. It is a combination of two different analysis which is factor analysis and regression analysis which is used to analyze the relation in between measure and latent variable as well as high aspects in a lower structures environment (Dijkstra \&Henseler, 2015).

Partial Least Square-SEM modeling of structural equation is appropriate for the study of a compound framework used in a research (Henseler et al., 2014). However, Structural Equation Modeling technique is used to examine the collected data (Ringle, Wende, \&Becker, 2014).

\subsection{Descriptive Analysis:}

Table 4.3

Respondents' Profile

\begin{tabular}{|c|c|c|c|}
\hline Variable & Category & Frequency & Percentage \\
\hline \multirow{3}{*}{ Age } & $20-30$ & 221 & $73.7 \%$ \\
\cline { 2 - 4 } & $31-40$ & 67 & 22.3 \\
\cline { 2 - 4 } & $41-50$ & 10 & 3.3 \\
\cline { 2 - 4 } & Above 50 & 2 & 0.7 \\
\hline \multirow{2}{*}{ Gender } & Male & 187 & 37.7 \\
\cline { 2 - 4 } & Female & 113 & 72.7 \\
\hline \multirow{3}{*}{ Working Experience } & $0-5$ Years & 218 & 18.7 \\
\cline { 2 - 4 } & $6-10$ Years & 56 & 7 \\
\cline { 2 - 4 } & $11-15$ Years & 21 & 1.7 \\
\hline
\end{tabular}

To change gathered data into information that can easily be understand and help researchers to explain their findings. Descriptive analysis helps researchers to rearrangeor interpret the responses as per their results (Zikmund, 2003). Descriptive Analysis consists of mean, Median and Mode. Mean shows the average of the data. Median is the middle value of the data however mode is the values that appear the most in the gathered data.

The sample of targeted population represented responses from various individuals, out of the total 300 respondents in which 187 of the respondents were males contributing about $62.3 \%$ of the total sample size whereas 113 of the females are making up to $37.7 \%$. 221 of the employee's aged between $20-30$ yearsmaking $73.7 \%$ while 
67 employees are aged between 31-40 years contributing 22.3\%, 10 employees are aged between 41 to 50 years comprising of $3.3 \%$ whereas employees above 50 are 2 contributing $0.7 \%$.

The experience levels also varied throughout the responses. As divided on the basis of working experience; 218 of the respondents has an experience about $0-5$ years contributing $72.7 \%, 56$ respondents has an experience of 6-10 years contributing about $18.7 \%$ whereas, $21 \& 5$ respondents has an experience of $11-15$ years \& above 50 years contributing $7 \% \& 1.7 \%$ respectively.

\section{Descriptive Statistic}

\begin{tabular}{|c|c|c|c|c|c|c|}
\hline \multirow{2}{*}{$\begin{array}{l}\text { Variables } \\
\text { and } \\
\text { Factors }\end{array}$} & \multirow{2}{*}{ Questions } & \multicolumn{2}{|c|}{ Descriptive Stats } & \multicolumn{3}{|c|}{$\begin{array}{l}\text { Confirmatory Factor } \\
\text { Analysis }\end{array}$} \\
\hline & & Mean & $\begin{array}{l}\text { standard } \\
\text { deviation }\end{array}$ & $\begin{array}{l}\text { outer } \\
\text { Loading }\end{array}$ & Stats & Values \\
\hline \multirow[b]{6}{*}{ 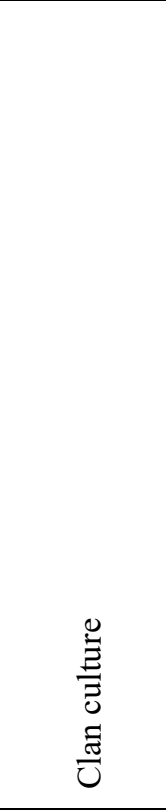 } & $\begin{array}{l}\text { The organization is a very personal place. } \\
\text { It is like an extended family. People seem } \\
\text { to share a lot of themselves. }\end{array}$ & 0.866 & 0.020 & 0.864 & 42.215 & 0.000 \\
\hline & $\begin{array}{l}\text { The leadership in the organization is } \\
\text { generally considered to exemplify } \\
\text { mentoring, facilitating or nurturing. }\end{array}$ & 0.909 & 0.013 & 0.909 & 70.731 & 0.000 \\
\hline & $\begin{array}{l}\text { The management style in the organization } \\
\text { is characterized by teamwork, consensus } \\
\text { and participation. }\end{array}$ & 0.906 & 0.012 & 0.906 & 74.726 & 0.000 \\
\hline & $\begin{array}{l}\text { The glue that holds the organization } \\
\text { together is loyalty and mutual trust. } \\
\text { Commitment to this organization runs } \\
\text { high. }\end{array}$ & 0.915 & 0.012 & 0.915 & 77.012 & 0.000 \\
\hline & $\begin{array}{l}\text { The organization emphasizes human } \\
\text { development. High trust, openness, and } \\
\text { participation persist. }\end{array}$ & 0.985 & 0.014 & 0.895 & 62.095 & 0.000 \\
\hline & $\begin{array}{l}\text { The organization defines success on the } \\
\text { basis of the development of human } \\
\text { resources, teamwork, employee } \\
\text { commitment, and concern for people. }\end{array}$ & 0.908 & 0.013 & 0.908 & 70.414 & 0.000 \\
\hline \multirow{6}{*}{ 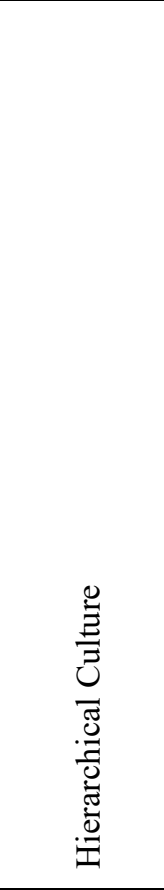 } & $\begin{array}{l}\text { The organization is a very controlled and } \\
\text { structured place. Formal procedures } \\
\text { generally govern what people do. }\end{array}$ & 0.824 & 0.023 & 0.842 & 36.336 & 0.000 \\
\hline & $\begin{array}{l}\text { The leadership in the organization is } \\
\text { generally considered to exemplify } \\
\text { coordinating, organizing or smooth - } \\
\text { running and efficiency. }\end{array}$ & 0.864 & 0.017 & 0.866 & 51.977 & 0.000 \\
\hline & $\begin{array}{l}\text { The management style in the organization } \\
\text { is characterized by security of } \\
\text { employment, conformity, predictability, } \\
\text { and stability in relationships. }\end{array}$ & 0.900 & 0.014 & 0.901 & 65.908 & 0.000 \\
\hline & $\begin{array}{l}\text { The glue that holds the organization } \\
\text { together is formal rules and policies. } \\
\text { Maintaining a smoothly running } \\
\text { organization is important. }\end{array}$ & 0.875 & 0.021 & 0.876 & 41.760 & 0.000 \\
\hline & $\begin{array}{l}\text { The organization emphasizes permanence } \\
\text { and stability. Efficiency, control, and } \\
\text { smooth operations are important. }\end{array}$ & 0.880 & 0.017 & 0.880 & 52.032 & 0.000 \\
\hline & $\begin{array}{l}\text { The organization defines success on the } \\
\text { basis of efficiency. Dependable delivery, } \\
\text { smooth scheduling and low-cost } \\
\text { production are critical. }\end{array}$ & 0.850 & 0.022 & 0.850 & 38.348 & 0.000 \\
\hline 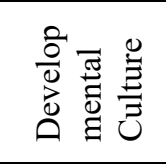 & $\begin{array}{l}\text { The company I work in is a very dynamic } \\
\text { and entrepreneurial place. People are } \\
\text { willing to stick their necks out and take } \\
\text { risks. }\end{array}$ & 0.893 & 0.015 & 0.892 & 61.499 & 0.000 \\
\hline
\end{tabular}




\begin{tabular}{|c|c|c|c|c|c|c|}
\hline \multirow{4}{*}{$\begin{array}{l}\text { Variables } \\
\text { and } \\
\text { Factors }\end{array}$} & \multirow{2}{*}{ Questions } & \multicolumn{2}{|c|}{ Descriptive Stats } & \multicolumn{3}{|c|}{$\begin{array}{l}\text { Confirmatory Factor } \\
\text { Analysis }\end{array}$} \\
\hline & & Mean & $\begin{array}{l}\text { standard } \\
\text { deviation }\end{array}$ & $\begin{array}{l}\text { outer } \\
\text { Loading }\end{array}$ & Stats & Values \\
\hline & $\begin{array}{l}\text { The glue that holds the company I work in } \\
\text { together is commitment to innovation and } \\
\text { development. There is an emphasis on } \\
\text { being first with products and services. }\end{array}$ & 0.894 & 0.015 & 0.895 & 60.922 & 0.000 \\
\hline & $\begin{array}{l}\text { The company I work in emphasizes } \\
\text { growth through acquiring new resources. } \\
\text { Acquiring new products/services to meet } \\
\text { new challenges is important. }\end{array}$ & 0.925 & 0.009 & 0.924 & 108.095 & 0.000 \\
\hline \multirow{3}{*}{ 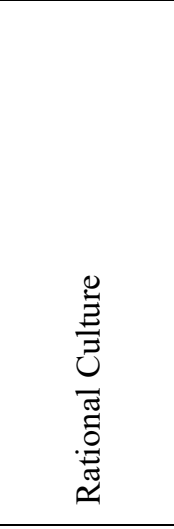 } & $\begin{array}{l}\text { The company I work in is a very } \\
\text { production-oriented place. People are } \\
\text { concerned with getting the job done and } \\
\text { are not very personally involved }\end{array}$ & 0.885 & 0.019 & 0.885 & 46.560 & 0.000 \\
\hline & $\begin{array}{l}\text { The glue that holds the company I work in } \\
\text { together is an emphasis on tasks and goal } \\
\text { accomplishment. A production and } \\
\text { achievement orientation is commonly } \\
\text { shared. }\end{array}$ & 0.924 & 0.011 & 0.923 & 82.608 & 0.000 \\
\hline & $\begin{array}{l}\text { The company I work in emphasizes } \\
\text { competitive actions, outcomes, and } \\
\text { achievement. Accomplishing measurable } \\
\text { goals is important. }\end{array}$ & 0.904 & 0.015 & 0.904 & 61.676 & 0.000 \\
\hline \multirow{4}{*}{ 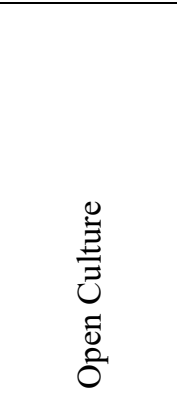 } & $\begin{array}{l}\text { This company is flexible and adaptable in } \\
\text { how it deals with difficulties. }\end{array}$ & 0.876 & 0.018 & 0.876 & 48.333 & 0.000 \\
\hline & $\begin{array}{l}\text { This company approaches problems with } \\
\text { a positive mind set Members of this } \\
\text { company are always able to help each } \\
\text { other when the need arises. }\end{array}$ & 0.917 & 0.013 & 0.918 & 73.424 & 0.000 \\
\hline & $\begin{array}{l}\text { This company knows it has the power to } \\
\text { solve major problems. }\end{array}$ & 0.883 & 0.018 & 0.884 & 49.388 & 0.000 \\
\hline & $\begin{array}{l}\text { This company when faced with } \\
\text { difficulties it works together effectively }\end{array}$ & 0.909 & 0.011 & 0.908 & 81.610 & 0.000 \\
\hline \multirow{12}{*}{ 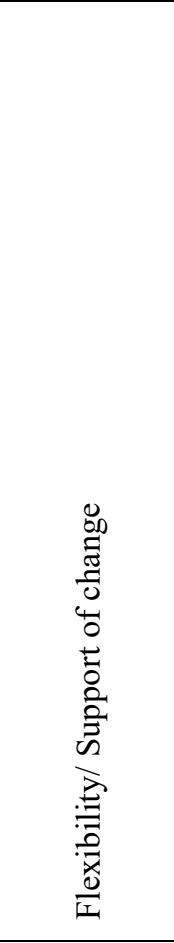 } & $\begin{array}{l}\text { Informs employees regarding } \\
\text { technological changes on a regular basis. }\end{array}$ & 0.772 & 0.026 & 0.770 & 29.929 & 0.000 \\
\hline & $\begin{array}{l}\text { This firm is aggressively pursuing } \\
\text { emerging business opportunities. }\end{array}$ & 0.768 & 0.028 & 0.766 & 27.523 & 0.000 \\
\hline & $\begin{array}{l}\text { Managers ask employees if there was a } \\
\text { better way to do things. }\end{array}$ & 0.826 & 0.026 & 0.825 & 32.079 & 0.000 \\
\hline & $\begin{array}{l}\text { This firm is committed to providing } \\
\text { training to employees. }\end{array}$ & 0.867 & 0.018 & 0.867 & 47.319 & 0.000 \\
\hline & $\begin{array}{l}\text { This firm is devoted for utilization of } \\
\text { innovative technology. }\end{array}$ & 0.879 & 0.015 & 0.879 & 59.050 & 0.000 \\
\hline & $\begin{array}{l}\text { The firm approaches problems with a } \\
\text { positive mindset. }\end{array}$ & 0.857 & 0.019 & 0.856 & 45.577 & 0.000 \\
\hline & $\begin{array}{l}\text { The firm knows it has the power to solve } \\
\text { major problems. }\end{array}$ & 0.845 & 0.024 & 0.844 & 35.004 & 0.000 \\
\hline & $\begin{array}{l}\text { Informs employees regarding change } \\
\text { thro' bulletins/teleconferences/others. }\end{array}$ & 0.851 & 0.020 & 0.850 & 41.926 & 0.000 \\
\hline & $\begin{array}{l}\text { This company aggressively pursuing } \\
\text { emerging business opportunities. }\end{array}$ & 0.840 & 0.020 & 0.39 & 41.409 & 0.000 \\
\hline & $\begin{array}{l}\text { Makes managers/family members an } \\
\text { accountable for change. }\end{array}$ & 0.815 & 0.023 & 0.816 & 35.055 & 0.000 \\
\hline & This company is committed to training. & 0.825 & 0.027 & 0.826 & 30.137 & 0.000 \\
\hline & $\begin{array}{l}\text { This company is committed to utilization } \\
\text { of technology. }\end{array}$ & 0.858 & 0.018 & 0.857 & 46.506 & 0.000 \\
\hline
\end{tabular}




\begin{tabular}{|c|c|c|c|c|c|c|}
\hline \multirow{3}{*}{$\begin{array}{l}\text { Variables } \\
\text { and } \\
\text { Factors }\end{array}$} & \multirow{2}{*}{ Questions } & \multicolumn{2}{|c|}{ Descriptive Stats } & \multicolumn{3}{|c|}{$\begin{array}{l}\text { Confirmatory Factor } \\
\text { Analysis }\end{array}$} \\
\hline & & Mean & $\begin{array}{l}\text { standard } \\
\text { deviation }\end{array}$ & $\begin{array}{l}\text { outer } \\
\text { Loading }\end{array}$ & Stats & Values \\
\hline & $\begin{array}{l}\text { This company recognizes where its } \\
\text { greatest assets were. }\end{array}$ & 0.839 & 0.020 & 0.838 & 42.152 & 0.000 \\
\hline \multirow{8}{*}{ 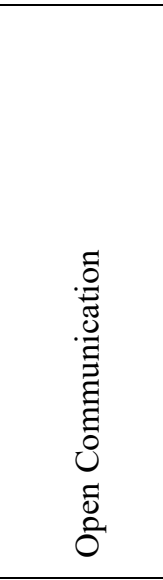 } & $\begin{array}{l}\text { We regularly talk about things that } \\
\text { concern us. }\end{array}$ & 0.846 & 0.023 & 0.846 & 37.077 & 0.000 \\
\hline & We take time to listen to each other. & 0.906 & 0.013 & 0.906 & 72.019 & 0.000 \\
\hline & We are frank with each other. & 0.864 & 0.020 & 0.863 & 42.697 & 0.000 \\
\hline & $\begin{array}{l}\text { There is open communication in the } \\
\text { organization. }\end{array}$ & 0.915 & 0.011 & 0.914 & 84.179 & 0.000 \\
\hline & $\begin{array}{l}\text { Everyone has the chance to express their } \\
\text { opinion. }\end{array}$ & 0.916 & 0.010 & 0.916 & 94.703 & 0.000 \\
\hline & $\begin{array}{l}\text { Team members maintain a high level of } \\
\text { idea of exchange. }\end{array}$ & 0.886 & 0.017 & 0.886 & 53.512 & 0.000 \\
\hline & $\begin{array}{l}\text { Employees and functional managers are } \\
\text { supportive to each other. }\end{array}$ & 0.880 & 0.018 & 0.880 & 49.639 & 0.000 \\
\hline & $\begin{array}{l}\text { Management encourages experimental } \\
\text { mind-set and risk taking. }\end{array}$ & 0.855 & 0.022 & 0.885 & 39.115 & 0.000 \\
\hline \multirow{8}{*}{ 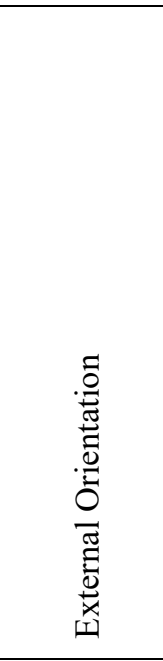 } & $\begin{array}{l}\text { This firm tracks changes in its markets on } \\
\text { a regular basis. }\end{array}$ & 0.850 & 0.019 & 0.850 & 45.885 & 0.000 \\
\hline & $\begin{array}{l}\text { This firm is preferably working with the } \\
\text { key customers and learning from them. }\end{array}$ & 0.858 & 0.022 & 0.859 & 38.964 & 0.000 \\
\hline & $\begin{array}{l}\text { The firm values are learning from the } \\
\text { activities of its competitors. }\end{array}$ & 0.861 & 0.017 & 0.860 & 51.422 & 0.000 \\
\hline & $\begin{array}{l}\text { This firm pays attention to building } \\
\text { relationships with external stakeholders. }\end{array}$ & 0.841 & 0.024 & 0.841 & 34.538 & 0.000 \\
\hline & $\begin{array}{l}\text { This company values working with key } \\
\text { customers and learning from them. }\end{array}$ & 0.878 & 0.015 & 0.877 & 59.261 & 0.000 \\
\hline & $\begin{array}{l}\text { This company values working with key } \\
\text { suppliers and learning from them. }\end{array}$ & 0.881 & 0.015 & 0.880 & 58.319 & 0.000 \\
\hline & $\begin{array}{l}\text { This company values learning from the } \\
\text { actions of its competitors }\end{array}$ & 0.856 & 0.019 & 0.856 & 44.201 & 0.000 \\
\hline & $\begin{array}{l}\text { The firm values are working with an } \\
\text { external agent. }\end{array}$ & 0.845 & 0.022 & 0.846 & 37.761 & 0.000 \\
\hline \multirow{9}{*}{ 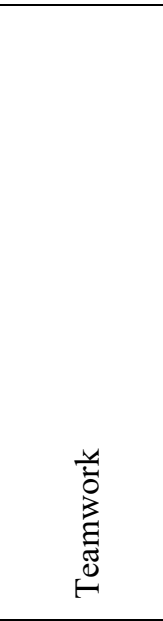 } & $\begin{array}{l}\text { There is a lot of group spirit in this } \\
\text { organization. }\end{array}$ & 0.878 & 0.016 & 0.877 & 55.869 & 0.000 \\
\hline & Employees work well with each other. & 0.892 & 0.013 & 0.891 & 69.420 & 0.000 \\
\hline & We all know each other well. & 0.883 & 0.017 & 0.883 & 53.021 & 0.000 \\
\hline & $\begin{array}{l}\text { We have social gatherings where } \\
\text { everyone in the company comes together. }\end{array}$ & 0.853 & 0.020 & 0.853 & 43.611 & 0.000 \\
\hline & $\begin{array}{l}\text { Management is friendly and } \\
\text { approachable. }\end{array}$ & 0.897 & 0.014 & 0.897 & 64.247 & 0.000 \\
\hline & We value being a team player. & 0.895 & 0.015 & 0.895 & 58.190 & 0.000 \\
\hline & $\begin{array}{l}\text { Non-family employees are trusted as } \\
\text { much as family employees. }\end{array}$ & 0.854 & 0.020 & 0.855 & 42.170 & 0.000 \\
\hline & $\begin{array}{l}\text { We value consensus in making key } \\
\text { decisions. }\end{array}$ & 0.836 & 0.027 & 0.837 & 31.092 & 0.000 \\
\hline & $\begin{array}{l}\text { Creating and preserving clear and explicit } \\
\text { practices are important to us }\end{array}$ & 0.869 & 0.019 & 0.868 & 46.102 & 0.000 \\
\hline \multirow{2}{*}{ 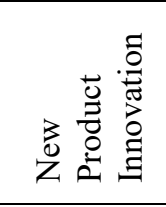 } & $\begin{array}{l}\text { In developing new products adhering to } \\
\text { product specifications and minimizing } \\
\text { experimentation is not at all important. }\end{array}$ & 0.778 & 0.033 & 0.779 & 23.901 & 0.000 \\
\hline & $\begin{array}{l}\text { Our customers provide specifications for } \\
\text { new products }\end{array}$ & 0.848 & 0.018 & 0.848 & 46.131 & 0.000 \\
\hline
\end{tabular}




\begin{tabular}{|c|c|c|c|c|c|c|}
\hline \multirow{7}{*}{$\begin{array}{l}\text { Variables } \\
\text { and } \\
\text { Factors }\end{array}$} & \multirow{2}{*}{ Questions } & \multicolumn{2}{|c|}{ Descriptive Stats } & \multicolumn{3}{|c|}{$\begin{array}{l}\text { Confirmatory Factor } \\
\text { Analysis }\end{array}$} \\
\hline & & Mean & $\begin{array}{l}\text { standard } \\
\text { deviation }\end{array}$ & $\begin{array}{l}\text { outer } \\
\text { Loading }\end{array}$ & Stats & Values \\
\hline & $\begin{array}{l}\text { The company's growth rate of sales has } \\
\text { increased as a result of introducing new } \\
\text { product/service. }\end{array}$ & 0.854 & 0.020 & 0.853 & 42.776 & 0.000 \\
\hline & $\begin{array}{l}\text { Paying attention to product specification } \\
\text { during product development is essential. }\end{array}$ & 0.854 & 0.018 & 0.854 & 48.404 & 0.000 \\
\hline & $\begin{array}{l}\text { Management actively responds to the } \\
\text { adoption of "new ways of doing things" } \\
\text { by main competitors. }\end{array}$ & 0.880 & 0.017 & 0.879 & 51.200 & 0.000 \\
\hline & $\begin{array}{l}\text { We are willing to try new ways of doing } \\
\text { things and seek unusual, novel solutions. }\end{array}$ & 0.887 & 0.013 & 0.886 & 68.123 & 0.000 \\
\hline & $\begin{array}{l}\text { We encourage people to think and behave } \\
\text { in original and novel ways. }\end{array}$ & 0.836 & 0.022 & 0.835 & 38.770 & 0.000 \\
\hline \multirow{7}{*}{ 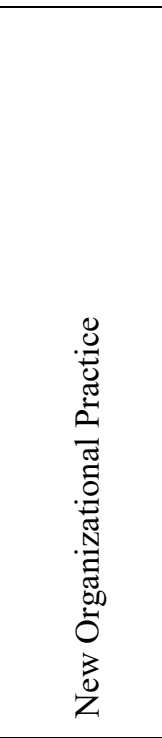 } & $\begin{array}{l}\text { Implementation of new business concepts } \\
\text { and practices will enhance employee's } \\
\text { innovation skills. }\end{array}$ & 0.838 & 0.033 & 0.838 & 38.064 & 0.000 \\
\hline & $\begin{array}{l}\text { Changing organizational structure is } \\
\text { significant to promote organizational } \\
\text { innovation. }\end{array}$ & 0.858 & 0.015 & 0.858 & 41.379 & 0.000 \\
\hline & $\begin{array}{l}\text { Introduce technology innovation } \\
\text { programs to employees will boost the } \\
\text { organizational innovation. }\end{array}$ & 0.889 & 0.020 & 0.889 & 60.248 & 0.000 \\
\hline & $\begin{array}{l}\text { My organization is being first in industry } \\
\text { to develop innovative management } \\
\text { systems. }\end{array}$ & 0.827 & 0.018 & 0.827 & 36.703 & 0.000 \\
\hline & $\begin{array}{l}\text { My organization is being first to introduce } \\
\text { new business concepts and practices. }\end{array}$ & 0.835 & 0.017 & 0.835 & 41.462 & 0.000 \\
\hline & $\begin{array}{l}\text { Changing organizational structure } \\
\text { significantly to promote innovation. }\end{array}$ & 0.869 & 0.013 & 0.869 & 52.565 & 0.000 \\
\hline & $\begin{array}{l}\text { Introduce innovative HRM programmes } \\
\text { to spur creativity and innovation. }\end{array}$ & 0.870 & 0.022 & 0.870 & 53.394 & 0.000 \\
\hline \multirow{3}{*}{ 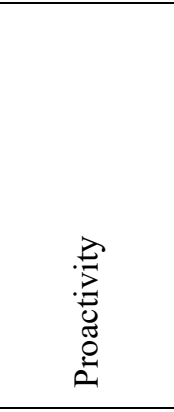 } & $\begin{array}{l}\text { In general, the top managers of our } \\
\text { organization favor a strong emphasis on } \\
\text { research and development, technological } \\
\text { leadership, and innovations. }\end{array}$ & 0.914 & 0.012 & 0.913 & 77.123 & 0.000 \\
\hline & $\begin{array}{l}\text { In the past five years, our organization has } \\
\text { marketed a large variety of new lines of } \\
\text { products or services. }\end{array}$ & 0.914 & 0.012 & 0.914 & 78.112 & 0.000 \\
\hline & $\begin{array}{l}\text { In the past five years, changes in our } \\
\text { products or service lines have been mostly } \\
\text { of a minor nature. }\end{array}$ & 0.879 & 0.018 & 0.879 & 47.567 & 0.000 \\
\hline \multirow[b]{3}{*}{ 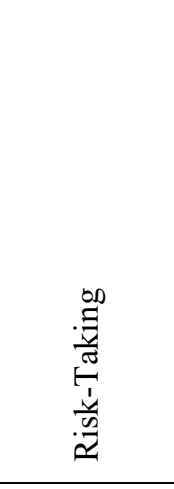 } & $\begin{array}{l}\text { In general, the top managers of my } \\
\text { organization have a strong propensity for } \\
\text { high-risk projects (with chances of very } \\
\text { high return). }\end{array}$ & 0.917 & 0.012 & 0.916 & 77.663 & 0.000 \\
\hline & $\begin{array}{l}\text { The top managers believe, owing to the } \\
\text { nature of the environment, that bold, } \\
\text { wide-ranging acts are necessary to } \\
\text { achieve our organization objectives. }\end{array}$ & 0.930 & 0.011 & 0.930 & 82.405 & 0.000 \\
\hline & $\begin{array}{l}\text { When there is uncertainty, our } \\
\text { organization typically adopts a "wait-and- } \\
\text { see" posture in order to minimize the } \\
\text { probability of making costly decisions. }\end{array}$ & 0.876 & 0.020 & 0.875 & 42.858 & 0.000 \\
\hline
\end{tabular}




\subsubsection{STRUCTURAL EQUATION MODELING}

To test the study hypothesis we have used the structural equation model (SEM) whereas the testing has been gone through Smart PLS software. Moreover, to evaluate the indirect and direct effects of all the constructs the testing was done. The use of (SEM) structural equation model has been observed to be a foremost procedure that has been used below different regression models and methods (Barron \& Kenny, 1986). It used to evaluate the structural relationship between exogenous and endogenous variables. It includes factor analysis and multivariate analysis. Moreover, the equation of regression targets at explaining each construct to assess the cause and effect relationship while all of the factors in the causal model could demonstrate their cause and effect at exact time. Likewise, the idea of using this model ensures to apply technique of bootstrapping which has been viewed as reasonable for both small and large sample size and does not require any kind of indirect effect (Hayes, 2013). In order to check the all direct and indirect effects, a technique has been implemented which is known as bootstrapping (Shrout\& Bolger, 2002).

\section{Measurement of Outer Model}

The goal of measure of fit in the measurement model is to study about the reliability and validity of the instrument and to check its reliability and validity we perform test of convergent validity and discriminant validity in software naming Smart PLS.

\section{Composite Reliability}

\begin{tabular}{|l|c|}
\hline & Composite Reliability \\
\hline Clan Culture & 0.962 \\
\hline Developmental Culture & 0.931 \\
\hline External Orientation & 0.957 \\
\hline Flexibility & 0.967 \\
\hline Hierarchical Culture & 0.948 \\
\hline New Organizational Practice & 0.950 \\
\hline New Product Innovation & 0.947 \\
\hline Open Communication & 0.966 \\
\hline Open Culture & 0.943 \\
\hline Proactivity & 0.930 \\
\hline Rational Culture & 0.931 \\
\hline
\end{tabular}

Reliability implies stability of questionnaire outcomes. For the similar target population, at whatever point the questioner reutilize the questionnaire it will give similar outcome. It demonstrates inside consistency \& repeatability of the survey is high. The primary measure for unwavering quality is to maintain a strategic distance from unfairness in research. In this manner, it tends to be improved by testing the pursuit procedure and investigation, as is done utilizing diverse research and examination techniques or different researchers. This also incorporates the dependability and legitimacy of the exploration.

Reliability of the measurement instruments was evaluated using composite reliability. All the values were above the normally used threshold value i.e. 0.70. This is the accepted reliabity value range. Estimation of reliability can be done by degree of constancy that lies amongst various variables (Hair, 2010)

\section{Factor loadings significant}

Table of descriptive statistics also mentioned loadings used in (CFA) confirmatory factor analysis. Construct with the loading of .5 are consider as strong loading variables whereas the constructs with the loading of below .5 are considered as less are better to be removed from the table.

\section{Convergent Validity:}

For the calculation of items of individual reliability as proposed by Tabachnick and Fidell (2007) a Partial Least square Algorithm is performed. In this the range is greater than 0.5 moreover, all the items involve in this study have the loadings above 0.5 as shown in table that is measurement model results. Moreover, these techniques are the part of PLS Algorithm that help to determine the convergent validity of our measured framework (Fornell\&Larcker, 1981), Cronbach's alpha, composite reliability and AVE.

As the table shows that all the values of Cronbach's alpha is greater than 0.7 (Cronbach, 1951) which indicates thatall the variables are reliable, Secondly, all the variables also as per the composite reliability requirement which says that all the values must be greater than 0.7 (Nunnally, 1978). Additionally, for the purpose of analyzing the convergent validity Fornell and Larcker (1981) suggested that the value of AVE should be greater than 0.5 and table of this study represent all values which are greater than 0.5 showing that the considered scales were appropriate to explain the variable. 
Table 4.3.4.1

Convergent validity

\begin{tabular}{|c|c|c|c|c|}
\hline Constructs & Loadings & Cronbach's & Composite Reliability & Average Variance Extracted \\
\hline Clan1 & 0.864 & & & \\
\hline Clan2 & 0.909 & 0.953 & 0.962 & 0.809 \\
\hline Clan3 & 0.906 & & & \\
\hline Clan4 & 0.915 & & & \\
\hline Clan5 & 0.895 & & & \\
\hline Clan6 & 0.908 & & & \\
\hline Developmental1 & 0.892 & & & \\
\hline Developmental2 & 0.895 & 0.888 & 0.931 & 0.817 \\
\hline Developmental3 & 0.924 & & & \\
\hline ExternalOrien 1 & 0.850 & & & \\
\hline ExternalOrien2 & 0.859 & 0.949 & 0.957 & 0.737 \\
\hline ExternalOrien3 & 0.860 & & & \\
\hline ExternalOrien4 & 0.841 & & & \\
\hline ExternalOrien5 & 0.877 & & & \\
\hline ExternalOrien6 & 0.880 & & & \\
\hline ExternalOrien7 & 0.856 & & & \\
\hline ExternalOrien8 & 0.846 & & & \\
\hline Flexibility1 & 0.770 & 0.963 & 0.967 & 0.696 \\
\hline Flexibility10 & 0.816 & & & \\
\hline Flexibility11 & 0.826 & & & \\
\hline Flexibility 12 & 0.857 & & & \\
\hline Flexibility13 & 0.838 & & & \\
\hline Flexibility2 & 0.766 & & & \\
\hline Flexibility3 & 0.825 & & & \\
\hline Flexibility4 & 0.867 & & & \\
\hline Flexibility 5 & 0.879 & & & \\
\hline Flexibility6 & 0.856 & & & \\
\hline Flexibility7 & 0.844 & & & \\
\hline Flexibility 8 & 0.850 & & & \\
\hline Flexibility9 & 0.839 & & & \\
\hline Hierarchical1 & 0.824 & 0.934 & 0.948 & 0.751 \\
\hline Hierarchical2 & 0.866 & & & \\
\hline Hierarchical3 & 0.901 & & & \\
\hline Hierarchical4 & 0.876 & & & \\
\hline Hierarchical5 & 0.880 & & & \\
\hline Hierarchical6 & 0.850 & & & \\
\hline NewOrganiz1 & 0.838 & 0.939 & 0.950 & 0.732 \\
\hline NewOrganiz2 & 0.858 & & & \\
\hline NewOrganiz3 & 0.889 & & & \\
\hline NewOrganiz4 & 0.827 & & & \\
\hline NewOrganiz5 & 0.835 & & & \\
\hline NewOrganiz6 & 0.869 & & & \\
\hline NewOrganiz7 & 0.870 & & & \\
\hline NewProduct1 & 0.779 & 0.935 & 0.947 & 0.720 \\
\hline NewProduct2 & 0.848 & & & \\
\hline NewProduct3 & 0.853 & & & \\
\hline NewProduct4 & 0.854 & & & \\
\hline NewProduct5 & 0.879 & & & \\
\hline NewProduct6 & 0.886 & & & \\
\hline NewProduct7 & 0.835 & & & \\
\hline OpenC1 & 0.876 & 0.960 & 0.966 & 0.781 \\
\hline OpenC2 & 0.918 & & & \\
\hline OpenC3 & 0.884 & & & \\
\hline
\end{tabular}




\begin{tabular}{|c|c|c|c|c|}
\hline Constructs & Loadings & Cronbach's & Composite Reliability & Average Variance Extracted \\
\hline OpenC4 & 0.908 & & & \\
\hline OpenCom 1 & 0.846 & 0.919 & 0.943 & 0.804 \\
\hline OpenCom2 & 0.906 & & & \\
\hline OpenCom3 & 0.863 & & & \\
\hline OpenCom4 & 0.914 & & & \\
\hline OpenCom5 & 0.916 & & & \\
\hline OpenCom6 & 0.886 & & & \\
\hline OpenCom7 & 0.880 & & & \\
\hline OpenCom8 & 0.855 & & & \\
\hline Proactivity1 & 0.913 & 0.887 & 0.930 & 0.815 \\
\hline Proactivity 2 & 0.914 & & & \\
\hline Proactivity 3 & 0.879 & & & \\
\hline Rational1 & 0.885 & 0.888 & 0.931 & 0.817 \\
\hline Rational2 & 0.923 & & & \\
\hline Rational3 & 0.904 & & & \\
\hline Risk1 & 0.916 & 0.892 & 0.933 & 0.823 \\
\hline Risk2 & 0.930 & & & \\
\hline Risk3 & 0.875 & & & \\
\hline TeamWork1 & 0.877 & 0.961 & 0.966 & 0.762 \\
\hline TeamWork2 & 0.891 & & & \\
\hline TeamWork3 & 0.883 & & & \\
\hline TeamWork4 & 0.853 & & & \\
\hline TeamWork5 & 0.897 & & & \\
\hline TeamWork6 & 0.895 & & & \\
\hline TeamWork7 & 0.855 & & & \\
\hline TeamWork8 & 0.837 & & & \\
\hline TeamWork9 & 0.868 & & & \\
\hline
\end{tabular}

In this model the value range of Cronbach alpha is from 0.961 to 0.926 as shown in the above table that predicts the data is reliable to perform further tests. The connection of each variable to the primary factor is articulated is predicted by the factor loading. Therefore it shows that scales used for variables has convergent validity.

\section{Discriminant validity}

This technique is implied to examine the difference between variables of the research framework.

\begin{tabular}{|l|l|l|l|l|l|l|l|l|l|l|l|l|l|} 
1.3.5. & \multicolumn{1}{l}{ Fornell and Larcker Criteria } \\
\hline & 1 & 2 & 3 & 4 & 5 & 6 & 7 & 8 & 9 & 10 & 11 & 12 & 13 \\
\hline Clan Culture 1 & 0.9 & & & & & & & & & & & & \\
\hline $\begin{array}{l}\text { Developmental } \\
\text { Culture 2 }\end{array}$ & 0.551 & 0.904 & & & & & & & & & & \\
\hline $\begin{array}{l}\text { External Orientation } \\
3\end{array}$ & 0.38 & 0.381 & 0.859 & & & & & & & & & & \\
\hline Flexibility 4 & 0.547 & 0.38 & 0.629 & 0.834 & & & & & & & & & \\
\hline $\begin{array}{l}\text { Hierarchical Culture } \\
5\end{array}$ & 0.215 & 0.219 & 0.465 & 0.561 & 0.867 & & & & & & & & \\
\hline $\begin{array}{l}\text { New Organizational } \\
\text { Practice 6 }\end{array}$ & 0.547 & 0.541 & 0.252 & 0.372 & 0.279 & 0.855 & & & & & & & \\
\hline $\begin{array}{l}\text { New Product } \\
\text { Innovation 7 }\end{array}$ & 0.321 & 0.393 & 0.628 & 0.55 & 0.516 & 0.245 & 0.849 & & & & & & \\
\hline $\begin{array}{l}\text { Open } \\
\text { Communication 8 }\end{array}$ & 0.51 & 0.604 & 0.209 & 0.219 & 0.358 & 0.609 & 0.301 & 0.884 & & & & & \\
\hline Open Culture 9 & 0.568 & 0.557 & 0.281 & 0.25 & 0.367 & 0.522 & 0.408 & 0.706 & 0.897 & & & & \\
\hline Proactivity 10 & 0.303 & 0.402 & 0.588 & 0.421 & 0.443 & 0.231 & 0.557 & 0.373 & 0.39 & 0.903 & & & \\
\hline Rational Culture 11 & 0.342 & 0.357 & 0.511 & 0.476 & 0.457 & 0.23 & 0.547 & 0.358 & 0.291 & 0.497 & 0.904 & & \\
\hline Risk-Taking 12 & 0.443 & 0.546 & 0.377 & 0.383 & 0.289 & 0.604 & 0.265 & 0.496 & 0.404 & 0.354 & 0.321 & 0.907 & \\
\hline Team Work 13 & 0.528 & 0.531 & 0.193 & 0.353 & 0.371 & 0.588 & 0.297 & 0.728 & 0.656 & 0.3 & 0.319 & 0.498 & 0.873 \\
\hline
\end{tabular}


Table 4.3.6Fornell and Larcker Table

It determines the extent of disparities between the overlying construct. Table 4.3.6 reveals the outcome of Discriminant validity as it exposes that how much any single factor is not the same as alternate factors in the model. Fornell and Larcker (1981) developed the test in which the mix affiliation between variables attained were compared and the transform eliminated estimations for the constructs building up every pair equivalent. According to Jaw (1998), the Discriminant validity is supported among variables which have an AVE more prominent than 0.5 entailing that no less than partial of inference variation was trapped by the variables.

\section{Heterotrait-Monotrait Ratio (HTMT):}

\begin{tabular}{|c|c|c|c|c|c|c|c|c|c|c|c|c|}
\hline & 1 & 2 & 3 & 4 & 5 & 6 & 7 & 8 & 9 & 10 & 11 & 12 \\
\hline \multicolumn{13}{|l|}{ Clan Culture } \\
\hline Developmental Culture & 0.595 & & & & & & & & & & & \\
\hline External Orientation & 0.398 & 0.412 & & & & & & & & & & \\
\hline Flexibility & 0.569 & 0.408 & 0.656 & & & & & & & & & \\
\hline Hierarchical Culture & 0.225 & 0.239 & 0.492 & 0.589 & & & & & & & & \\
\hline New Organizational Practice & 0.577 & 0.587 & 0.266 & 0.389 & 0.297 & & & & & & & \\
\hline New Product Innovation & 0.339 & 0.428 & 0.666 & 0.577 & 0.552 & 0.258 & & & & & & \\
\hline Open Communication & 0.533 & 0.652 & 0.217 & 0.224 & 0.377 & 0.639 & 0.316 & & & & & \\
\hline Open Culture & 0.607 & 0.612 & 0.298 & 0.263 & 0.394 & 0.558 & 0.438 & 0.749 & & & & \\
\hline Proactivity & 0.326 & 0.448 & 0.637 & 0.448 & 0.481 & 0.251 & 0.607 & 0.401 & 0.430 & & & \\
\hline Rational Culture & 0.369 & 0.397 & 0.555 & 0.510 & 0.500 & 0.250 & 0.597 & 0.387 & 0.320 & 0.556 & & \\
\hline Risk-Taking & 0.479 & 0.610 & 0.406 & 0.409 & 0.315 & 0.658 & 0.289 & 0.534 & 0.444 & 0.395 & 0.358 & \\
\hline Team Work & 0.551 & 0.572 & 0.198 & 0.363 & 0.389 & 0.616 & 0.310 & 0.756 & 0.696 & 0.318 & 0.340 & 0.534 \\
\hline
\end{tabular}

Another method for checking the Discriminant validity is by using Heterotrait-monotrait (HTMT) ratio of correlation. Henseler et al. (2015) anticipated the better functioning of this technique by Monte Carlo simulation study and established that HTMT is able to achieve higher specificity and sensitivity. HTMT values near to 1 show a lack of Discriminant validity. If the value of the HTMT is higher, this can be concluded that the data lack Discriminant validity.

HTMT values confirm the Discriminant validity of the model because all of the values of the variables are $<$ 0.9 and according to Henseler et al. (2015) it should be $<0.9$.

\section{Blindfolding}

A structural model analyzes the statistics concerning some endogenous latent variables to other latent variables. The most convenient feature in Partial Least Squares (PLS) method is that it can examine structural model and hypothesis through calculating path coefficients (Cohen, 1988). The hypotheses were tested by running a bootstrapping procedure as suggested by F.Hair Jr et al, (2014).

$\begin{array}{ll}\text { Table 4.3.8.1 } & \\ \text { Blind Folding } & \text { Q2 } \\ \text { R2 } & 0.32 \\ 0.497 & 0.65 \\ 0.547 & 0.44 \\ 0.460 & 0.43\end{array}$

$\begin{array}{llr}\text { New Organizational Practice } & 0.497 & 0.32 \\ \text { New Product Innovation } & 0.547 & 0.65 \\ \text { Proactivity } & 0.460 & 0.44 \\ \text { Risk-Taking } & 0.408 & 0.43\end{array}$

To analyze the connection between variables the values of R2 and Q2 are examined. The value less than 0.25 shows weak connection, value less than 0.50 shows moderate connection (Hair, Ringle \& Sarstedt, 2011) CMS has a strong connection shows by the value of R2 (Hair 2011), Q2 should be greater than zero which shows the overall model is fit (Stone \& Geisser, 1974). Q2 value of the variable define that variables are the higher predictor for the model. The result of Q2 in above table is 0.595 which is greater than zero that demonstrates that the overall model is fit and recommended further.

\section{Structural Model Analysis}

Chin's (1998) recommended that for the procedure of bootstrapping 1,000 subsamples were executed to determine the statistical significance of all proposed paths coefficients.

\section{Hypothesis Testing}

In PLS-SEM, bootstrapping is one of the key stride, which gives the data of constancy of factor guesstimate .Subtests are drawn everywhere from the first example including substitution, in this process (Hair, Matthews, Matthews, \& Sarstedt, 2017). Bootstrapping provides the information of stability of coefficient estimate. In this process, a large number of sub-samples are drawn from the original sample with replacement (Hair et al. 2016). After running the bootstrap routine, SmartPLS shows the t-values for structural model estimates derived from the bootstrapping procedure. The results of path coefficients for all the hypothesis are shown in the following table. The t-value greater than $1.96(\mathrm{p}<.005)$ shows that the relationship is significant at $95 \%$ confidence level $(\alpha=$ 0.05 ). Paths showing whether the relationship between measured and latent variables are significant or not. 
The value of the mention table represented the supported and not supported hypothesis of the research paper.

Table 4.4.1

Path Coefficients and Bootstrap Values

Hypothesis Summery

\begin{tabular}{|c|c|c|c|c|c|}
\hline Hypothesis & Relationship & $\begin{array}{l}\text { Original } \\
\text { Sample }\end{array}$ & T-Statistic & P-Value & Support \\
\hline $\mathrm{H}_{1 \mathrm{a}}$ & $\begin{array}{l}\text { Clan Culture -> New Organizational } \\
\text { Practice }\end{array}$ & 0.173 & 1.661 & 0.097 & supported \\
\hline $\mathrm{H}_{1 \mathrm{~b}}$ & $\begin{array}{l}\text { Clan Culture -> New Product } \\
\text { Innovation }\end{array}$ & -0.156 & 1.712 & 0.087 & supported \\
\hline $\mathrm{H}_{1 \mathrm{c}}$ & Clan Culture -> Proactivity & -0.102 & 1.102 & 0.271 & Not-supported \\
\hline $\mathrm{H}_{1 \mathrm{~d}}$ & Clan Culture -> Risk-Taking & 0.061 & 0.558 & 0.577 & Not-supported \\
\hline $\mathrm{H}_{2 \mathrm{a}}$ & $\begin{array}{l}\text { Hierarchical Culture -> New } \\
\text { Organizational Practice }\end{array}$ & 0.008 & 0.098 & 0.922 & Not-supported \\
\hline $\mathrm{H}_{2 \mathrm{~b}}$ & $\begin{array}{l}\text { Hierarchical Culture -> New Product } \\
\text { Innovation }\end{array}$ & 0.112 & 1.493 & 0.136 & Not-supported \\
\hline $\mathrm{H}_{2 \mathrm{c}}$ & Hierarchical Culture -> Proactivity & 0.098 & 1.141 & 0.254 & Not-supported \\
\hline $\mathrm{H}_{2 \mathrm{~d}}$ & Hierarchical Culture -> Risk-Taking & 0.012 & 0.135 & 0.893 & Not-supported \\
\hline $\mathrm{H}_{3 \mathrm{a}}$ & $\begin{array}{l}\text { Developmental Culture -> New } \\
\text { Organizational Practice }\end{array}$ & 0.153 & 1.605 & 0.109 & Not-supported \\
\hline $\mathrm{H}_{3 \mathrm{~b}}$ & $\begin{array}{l}\text { Developmental Culture -> New } \\
\text { Product Innovation }\end{array}$ & 0.091 & 1.013 & 0.311 & Not-supported \\
\hline $\mathrm{H}_{3 \mathrm{c}}$ & Developmental Culture -> Proactivity & 0.095 & 1.189 & 0.235 & Not-supported \\
\hline $\mathrm{H}_{3 \mathrm{~d}}$ & Developmental Culture -> Risk-Taking & 0.270 & 2.970 & 0.003 & supported \\
\hline $\mathrm{H}_{4 \mathrm{a}}$ & $\begin{array}{l}\text { Rational Culture }->\text { New } \\
\text { Organizational Practice }\end{array}$ & -0.122 & 1.250 & 0.212 & Not-supported \\
\hline $\mathrm{H}_{4 \mathrm{~b}}$ & $\begin{array}{l}\text { Rational Culture -> New Product } \\
\text { Innovation }\end{array}$ & 0.222 & 2.597 & 0.010 & supported \\
\hline $\mathrm{H}_{4 \mathrm{c}}$ & Rational Culture -> Proactivity & 0.181 & 2.134 & 0.033 & supported \\
\hline $\mathrm{H}_{4 \mathrm{~d}}$ & Rational Culture -> Risk-Taking & -0.014 & 0.169 & 0.866 & Not-supported \\
\hline $\mathrm{H}_{5 \mathrm{a}}$ & $\begin{array}{l}\text { Open Culture -> New Organizational } \\
\text { Practice }\end{array}$ & 0.005 & 0.045 & 0.964 & Not-supported \\
\hline $\mathrm{H}_{5 \mathrm{~b}}$ & $\begin{array}{l}\text { Open Culture -> New Product } \\
\text { Innovation }\end{array}$ & 0.282 & 2.610 & 0.009 & supported \\
\hline $\mathrm{H}_{5 \mathrm{c}}$ & Open Culture -> Proactivity & 0.144 & 1.437 & 0.151 & Not-supported \\
\hline $\mathrm{H}_{5 \mathrm{~d}}$ & Open Culture -> Risk-Taking & -0.105 & 0.978 & 0.328 & Not-supported \\
\hline $\mathrm{H}_{6 \mathrm{a}}$ & $\begin{array}{l}\text { Flexibility -> New Organizational } \\
\text { Practice }\end{array}$ & 0.146 & 1.428 & 0.154 & Not-supported \\
\hline $\mathrm{H}_{6 \mathrm{~b}}$ & Flexibility -> New Product Innovation & 0.202 & 2.263 & 0.024 & supported \\
\hline $\mathrm{H}_{6 \mathrm{c}}$ & Flexibility -> Proactivity & 0.010 & 0.102 & 0.919 & Not-supported \\
\hline $\mathrm{H}_{6 \mathrm{~d}}$ & Flexibility -> Risk-Taking & 0.052 & 0.489 & 0.625 & Not-supported \\
\hline $\mathrm{H}_{7 \mathrm{a}}$ & $\begin{array}{l}\text { Open Communication -> New } \\
\text { Organizational Practice }\end{array}$ & 0.309 & 2.570 & 0.010 & supported \\
\hline $\mathrm{H}_{7 \mathrm{~b}}$ & $\begin{array}{l}\text { Open Communication }->\text { New Product } \\
\text { Innovation }\end{array}$ & -0.065 & 0.492 & 0.623 & Not-supported \\
\hline $\mathrm{H}_{7 \mathrm{c}}$ & Open Communication -> Proactivity & 0.119 & 1.079 & 0.281 & Not-supported \\
\hline $\mathrm{H}_{7 \mathrm{~d}}$ & Open Communication -> Risk-Taking & 0.174 & 1.495 & 0.136 & Not-supported \\
\hline $\mathrm{H}_{8 \mathrm{a}}$ & $\begin{array}{l}\text { External Orientation -> New } \\
\text { Organizational Practice }\end{array}$ & -0.005 & 0.046 & 0.963 & Not-supported \\
\hline $\mathrm{H}_{8 b}$ & $\begin{array}{l}\text { External Orientation -> New Product } \\
\text { Innovation }\end{array}$ & 0.304 & 3.360 & 0.001 & supported \\
\hline $\mathrm{H}_{8 \mathrm{c}}$ & External Orientation -> Proactivity & 0.391 & 4.765 & 0.000 & supported \\
\hline $\mathrm{H}_{8 \mathrm{~d}}$ & External Orientation -> Risk-Taking & 0.171 & 1.843 & 0.066 & supported \\
\hline $\mathrm{H}_{9 \mathrm{a}}$ & $\begin{array}{l}\text { Team Work -> New Organizational } \\
\text { Practice }\end{array}$ & 0.173 & 1.348 & 0.178 & Not-supported \\
\hline $\mathrm{H}_{9 \mathrm{~b}}$ & $\begin{array}{l}\text { Team Work -> New Product } \\
\text { Innovation }\end{array}$ & -0.050 & 0.403 & 0.687 & Not-supported \\
\hline
\end{tabular}




\begin{tabular}{|l|l|l|l|l|l|}
\hline Hypothesis & Relationship & $\begin{array}{l}\text { Original } \\
\text { Sample }\end{array}$ & T-Statistic & P-Value & Support \\
\hline $\mathrm{H}_{9 \mathrm{c}}$ & Team Work -> Proactivity & -0.051 & 0.442 & 0.658 & Not-supported \\
\hline $\mathrm{H}_{9 \mathrm{~d}}$ & Team Work -> Risk-Taking & 0.213 & 1.767 & 0.078 & supported \\
\hline
\end{tabular}

The hypotheses between the independent variables and dependent variables were evaluated on the foundation of significance $(p<0.1)$, sign and size (Wixom \& Watson, 2001). The results showed that new product innovation was positively influenced by Rational Culture, Open Culture, Flexibility, and External Orientation. And negatively affected by Clan Culture. Similarly, risk taking ability is positively influenced by Developmental Culture, External Orientation, and Team Work. Proactivity is positively affected by Rational Culture, and External Orientation. Unlike Innovation, which was negatively affected by Clan culture, New Organizational Practice got positively affected along with Open Communication. An approach calculates the indirect effect by multiplying two regression coefficients (Sobel, 1982).

The results showed that new product innovation was positively influenced by Rational Culture, Open Culture, Flexibility, and External Orientation. And negatively affected by Clan Culture. Similarly, risk taking ability is positively influenced by Developmental Culture, External Orientation, and Team Work. Proactivity is positively affected by Rational Culture, and External Orientation. Unlike Innovation, which was negatively affected by Clan culture, New Organizational Practice got positively affected along with Open Communication.

\section{Conclusion}

The objective of this research was to identify the impact of organizational culture on new product innovation, organizational practice, proactivity and risk taking. To achieve the objective of study instrument for organizational culture are; clan culture, hieratical culture, developmental culture, rational culture, open culture, flexibility/ support to change, open communication, external orientation and teamwork are derived from different studies done before in different time frame and different countries.

The sample chosen for this research paper is 300 out of 320 . In this research project, primary data had been collected by using survey questionnaires method. The discriminant validity and reliability of data was confirmed to validate the authenticity of the instrument. The data was screened through different method. The reliability, validity and SEM analysis were tested through Smart PLS 3. The reliability and validity of indicator was check through Log Algorithm path and for SEM analysis bootstrapping sample were used and for predictive relevance the option of blindfolding is used.

The present study contributes to the literature on Organizational culture to the new innovation process, organizational practice, pro-activity and risk-taking in different way. First, our results show that clan culture of any organization will definitely effect the new organizational practice and new product innovation of an organization because clan culture elaborates the unity, togetherness and whenever an organization have a clan culture it will deliver good results.

But on the other hand the strange result was seen that the hierarchical culture do not support any of our dependent variables. It may be due to the dominancy of the upper management on the employees. And also there is lack of communication between the departments or rivalry among the departments which undeniably effect the organization culture and fail to contribute in positive results. Also Developmental culture and team work only support the risk-taking by organization. It may be because whenever an organization decide to take risk for any project or any idea or any innovation, it require a culture within the organization which has the capability to work for the development and work within a team to achieve positive results. Also organizational factors like external orientation, flexibility, open communication, open culture and rational culture has significant effect on the new product innovation. Because whenever an organization provide free culture to the employees it absolutely provide positive results in future and in innovation of product.

A lot of researches were conducted on organizational culture and entrepreneurial orientation but no one has ever conduct a comparative or nexus research in which organizational culture was measured by teamwork, external orientation, developmental culture, rational culture, clan culture, open culture, open communication, flexibility/ support to change, hierarchical culture (altogether) and entrepreneurial orientation was measured by innovativeness, risk-taking, new organizational practice and proactiveness (altogether). This study has been positively contribute in this era because the working employees has giving their opinion through questionnaire and the conclusion support the organizations for better innovation of product, for new organizational practice, for proactive behavior and for taking risk.

\section{Limitations:}

The research is purely based on employees who are currently working in any organization so to distribute and collect questionnaire in due time was a tough duty, and this gives a negative impact on the data gathering and on the subject of research. Due to the limitation of time this study will have some lacking in context. Also facing trouble to get to the organization's inside data. 
Moreover, the research work is conducted for the employees who are currently working in any organization because the data is easily accessible. In this research we did not analyze any specific sector. In order to get accurate result, we randomly select employees. The findings of study are based on the test results which have been applied on the questionnaires filled online and manually as well. The research has not been applied on any organization and has been done for academic purpose.

\section{References}

Abdullah, N. H., Shamsuddin, A., Wahab, E., \& Hamid, N. A. A. (2014). The relationship between organizational culture and product innovativeness. Procedia-Social and Behavioral Sciences, 129, 140-147.

Arz, C. (2017). Mechanisms of organizational culture for fostering corporate entrepreneurship: A systematic review and research agenda. Journal of enterprising culture, 25(04), 361-409.

Atiyabi, F., Livari, M. A., \& Kaviani, K. (2007). Statistical analysis of heart beat time series. Iranian Journal of Physics Research, 7(1), 53-59.

Awadh, A. M., \& Alyahya, M. S. (2013). Impact of organizational culture on employee performance. International review of management and business research, 2(1), 168.

Brettel, M., Chomik, C., \& Flatten, T. C. (2015). How organizational culture influences innovativeness, proactiveness, and risk-taking: Fostering entrepreneurial orientation in SMEs. Journal of Small Business Management, 53(4), 868-885.

Bunderson, J. S., \& Sutcliffe, K. M. (2003). Management team learning orientation and business unit performance. Journal of Applied Psychology, 88(3), 552.

Carlsson, S., Corvello, V., Inauen, M., \& Schenker-Wicki, A. (2011). The impact of outside-in open innovation on innovation performance. European Journal of Innovation Management.

Cherchem, N. (2017). The relationship between organizational culture and entrepreneurial orientation in family firms: Does generational involvement matter?. Journal of family business strategy, 8(2), 87-98.

Chirico, F., \& Nordqvist, M. (2010). Dynamic capabilities and trans-generational value creation in family firms: The role of organizational culture. International Small Business Journal, 28(5), 487-504.

Cohen, N. J., McCloskey, M., \& Wible, C. G. (1988). There is still no case for a flashbulb-memory mechanism: Reply to Schmidt and Bohannon.

Cornwall, J. R., \& Perlman, B. (1990). Organizational entrepreneurship. McGraw-Hill/Irwin.

Covin, J. G., \& Slevin, D. P. (1991). A conceptual model of entrepreneurship as firm behavior. Entrepreneurship theory and practice, 16(1), 7-26.

Cronbach, L. J. (1951). Coefficient alpha and the internal structure of tests. psychometrika, 16(3), $297-334$.

Dijkstra, T. K., \& Henseler, J. (2015). Consistent partial least squares path modeling. MIS quarterly, $39(2)$.

Ekvall, G. (1996), "Organizational climate for creativity and innovation", European Journal of Work and Organizational Psychology, Vol. 5 No. 1, pp. 105-123.

Engelen, A., Flatten, T. C., Thalmann, J., \& Brettel, M. (2014). The effect of organizational culture on entrepreneurial orientation: A comparison between Germany and Thailand. Journal of small business management, 52(4), 732-752.

Faiz, E., \& Uludag, G. (2019). Entrepreneurial Orientation of Family Business: A Case Study From Turkey. In Handbook of Research on Entrepreneurship, Innovation, and Internationalization (pp. 133-156). IGI Global.

Fornell, C., \& Larcker, D. F. (1981). Structural equation models with unobservable variables and measurement error: Algebra and statistics.

George, B. C., Bohnen, J. D., Williams, R. G., Meyerson, S. L., Schuller, M. C., Clark, M. J., ... \& Smink, D. S. (2017). Readiness of US general surgery residents for independent practice. Annals of surgery, 266(4), 582594.

Gibbs, R. A., Weinstock, G. M., Metzker, M. L., Muzny, D. M., Sodergren, E. J., Scherer, S. \& Okwuonu, G. (2004). Genome sequence of the Brown Norway rat yields insights into mammalian evolution. Nature, 428(6982), 493-520.

Gil-Garcia, J. R. (2008, May). Using partial least squares (PLS) for digital government research. In Proceedings of the 2008 international conference on Digital government research (pp. 459-460). Digital Government Society of North America.

Gursoy, A., \& Guven, B. (2016). Effect of innovative culture on intrapreneurship. International Journal of Business and Social Science, 7(1), 152-162.

Hair Jr, J. F., Matthews, L. M., Matthews, R. L., \& Sarstedt, M. (2017). PLS-SEM or CB-SEM: updated guidelines on which method to use. International Journal of Multivariate Data Analysis, 1(2), 107-123.

Hair, J. F. (2010). Black, Wc, Babin, Bj, \& Anderson, Re (2010). Multivariate data analysis, 7.

Harkema, S. (2003). A complex adaptive perspective on learning within innovation projects. The learning organization.

Hayes, A. F., \& Scharkow, M. (2013). The relative trustworthiness of inferential tests of the indirect effect in 
statistical mediation analysis: Does method really matter?. Psychological science, 24(10), 1918-1927.

Henseler, J., Hubona, G., \& Ray, P. A. (2016). Using PLS path modeling in new technology research: updated guidelines. Industrial management \& data systems.

Hoque, N., Khan, M. A., \& Mowla, M. (2013). Organisational culture: features and framework from Islamic perspective. Humanomics.

Iivari, J., \& Huisman, M. (2007). The relationship between organizational culture and the deployment of systems development methodologies. Mis Quarterly, 35-58.

Katila, R., \& Ahuja, G. (2002). Something old, something new: A longitudinal study of search behavior and new product introduction. Academy of management journal, 45(6), 1183-1194.

Laforet, S. (2016). Effects of organisational culture on organisational innovation performance in family firms. Journal of Small Business and Enterprise Development, 23(2), 379-407.

Laursen, K., \& Salter, A. (2006). Open for innovation: the role of openness in explaining innovation performance among UK manufacturing firms. Strategic management journal, 27(2), 131-150.

Li, K., Griffi n, D., Yue, H., \& Zhao, L. (2013). How does culture influence corporate risk-taking? Journal of Corporate Finance, 23, 1-22

Lu, A. C. C., \& Gursoy, D. (2016). Impact of job burnout on satisfaction and turnover intention: do generational differences matter?. Journal of Hospitality \& Tourism Research, 40(2), 210-235.

Martín-de Castro, G., López-Sáez, P., Delgado-Verde, M., Donate, M. J., \& Guadamillas, F. (2011). Organizational factors to support knowledge management and innovation. Journal of knowledge management.

Miller, D., \& Friesen, P. H. (1983). Strategy-making and environment: the third link. Strategic management journal, 4(3), 221-235.

Nordqvist, M., \& Melin, L. (2010). Entrepreneurial families and family firms. Entrepreneurship \& Regional Development, 22(3-4), 211-239.

Pai, C. Y., Kuo, T. S., Jaw, T. J., Kurant, E., Chen, C. T., Bessarab, D. A., ... \& Sun, Y. H. (1998). The Homothorax homeoprotein activates the nuclear localization of another homeoprotein, extradenticle, and suppresses eye development in Drosophila. Genes \& development, 12(3), 435-446.

Pauwels, K., Silva-Risso, J., Srinivasan, S., \& Hanssens, D. M. (2004). New products, sales promotions, and firm value: The case of the automobile industry. Journal of marketing, 68(4), 142-156.

Prajogo, D.I. and McDermott, C. (2011), "The relationship between multidimensional organizational culture and performance", International Journal Operations \& Production Management, Vol. 31 No. 7, pp. 712-735.

Pullen, A., de Weerd-Nederhof, P., Groen, A., Song, M. and Fisscher, O. (2009), "Successful patterns of internal SME characteristics leading to high overall innovation performance", Creativity and Innovation Management, Vol. 18 No. 3, pp. 209-223.

Radas,S.andBozic,L.(2009), "The antecedents of SME innovativeness in an emerging transition economy”, Technovation, Vol. 29 Nos 6/7, pp. 438-450.

Rass, M., Dumbach, M., Danzinger, F., Bullinger, A. C., \& Moeslein, K. M. (2013). Open innovation and firm performance: the mediating role of social capital. Creativity and innovation management, 22(2), 177-194.

Reinartz,W.,Krafft,M.and Hoyer,W.D.(2004),“The customer relationship management process: measurement and impact on performance”, Journal of Marketing Research, Vol. 41 No. 3, pp. 293-305.

Riivari, E., Lämsä, A. M., Kujala, J., \& Heiskanen, E. (2012). The ethical culture of organisations and organisational innovativeness. European Journal of Innovation Management.

Ringle, C. M., Wende, S., \& Will, A. (2005). SmartPLS 2.0 M3 Beta.

Ringle, W. S. \& Becker, J.(2015)." SmartPLS 3." Boenningstedt: SmartPLS GmbH.

Rószkiewicz, M., \& Strzyżewska, M. (2011). The relationship between the commitment to internationalization and economic cooperation and changes in the level of sales profitability of Polish enterprises. The results of the empirical study, 'Management and Finance, (4/8), 319-331.

Salavou, H. and Avlonitis, G. (2008), "Product innovativeness and performance: a focus on SMEs", Management Decision, Vol. 46 No. 7, pp. 969-985.

Salavou, H., Baltas, G. and Lioukas, S. (2004), "Organisational innovation in SMEs: the importance of strategic orientation and competitive structure", European Journal of Marketing, Vol. 38 No. 9, pp. 1091-1112.

Sarstedt, M., Ringle, C. M., Henseler, J., \& Hair, J. F. (2014). On the emancipation of PLS-SEM: A commentary on Rigdon (2012). Long range planning, 47(3), 154-160.

Shahzad, F., Xiu, G., \&Shahbaz, M. (2017). Organizational culture and innovation performance in Pakistan's software industry. Technology in Society, 51, 66-73.

Shrout, P. E., \& Bolger, N. (2002). Mediation in experimental and nonexperimental studies: new procedures and recommendations. Psychological methods, 7(4), 422.

Simpson, P., \& Brauker, J. (2006). U.S. Patent Application No. 11/404,946.

Singh, T., \& Modassir, A. (2007). Relationship of emotional intelligence with transformational leadership and organizational citizenship behavior. IIM Bangalore Research Paper, (262). 
Sobel, M. E. (1982). Asymptotic confidence intervals for indirect effects in structural equation models. Sociological methodology, 13, 290-312.

Stone, M. (1974). Cross-validatory choice and assessment of statistical predictions. Journal of the Royal Statistical Society: Series B (Methodological), 36(2), 111-133.

Tabachnick, B. G., Fidell, L. S., \& Ullman, J. B. (2007). Using multivariate statistics (Vol. 5). Boston, MA: Pearson.

Tanewski, G.A., Prajogo, D. and Sohal, A. (2003), "Strategic orientation and innovation performance between family and non-family firms", presented at the World Conference of the International Council of Small Business, Monash University, Belfast, 15-18 June.

Thorne, J. H., Cameron, D., \& Quinn, J. F. (2006). A conservation design for the central coast of California and the evaluation of mountain lion as an umbrella species. Natural Areas Journal, 26(2), 137-148.

Wixom, B. H., \& Watson, H. J. (2001). An empirical investigation of the factors affecting data warehousing success. MIS quarterly, 17-41.

Zahra, S. A. (2008). The virtuous cycle of discovery and creation of entrepreneurial opportunities. Strategic Entrepreneurship Journal, 2(3), 243-257.

Zikmund, W. G., Babin, B. J., Carr, J. C., \& Griffin, M. (2003). Business research methods (ed.). Thomson/SouthWestern, Cincinnati, $\mathrm{OH}$. 